\title{
Managing Eutrophication in the Szczecin (Oder) Lagoon-Development, Present State and Future Perspectives
}

\author{
René Friedland $^{1 *}$, Gerald Schernewski ${ }^{1,2}$, Ulf Gräwe ${ }^{1}$, Inga Greipsland ${ }^{3}$, Dalila Palazzo ${ }^{1,4}$ \\ and Marianna Pastuszak ${ }^{5}$
}

${ }^{1}$ Leibniz-Institute for Baltic Sea Research Warnemünde, Rostock, Germany, ${ }^{2}$ Klaipeda University Marine Science and Technology Center, Klaipéda, Lithuania, ${ }^{3}$ Norwegian Institute of Bioeconomy Research, Ås, Norway, ${ }^{4}$ STA Engineering, Pinerolo, Italy, ${ }^{5}$ National Marine Fisheries Research Institute, Gdynia, Poland

\section{OPEN ACCESS}

Edited by:

Marianne Holmer,

University of Southern Denmark,

Denmark

Reviewed by: Angel Pérez-Ruzafa, University of Murcia, Spain Nafsika Papageorgiou, University of Crete, Greece

${ }^{*}$ Correspondence: René Friedland rene.friedland@io-warnemuende.de

Specialty section: This article was submitted to Marine Ecosystem Ecology, a section of the journal Frontiers in Marine Science

Received: 15 October 2018 Accepted: 21 December 2018

Published: 16 January 2019

Citation:

Friedland R, Schernewski G, Gräwe U, Greipsland I, Palazzo D and

Pastuszak M (2019) Managing Eutrophication in the Szczecin (Oder) Lagoon-Development, Present State and Future Perspectives.

Front. Mar. Sci. 5:521. doi: 10.3389/fmars.2018.00521
High riverine nutrient loads caused poor water quality, low water transparency and an unsatisfactory ecological status in the Szczecin (Oder) Lagoon, a trans-boundary water at the southern shore of the Baltic Sea. Total annual riverine $N(P)$ loads into the lagoon raised at the 20th century from approximately 14,000 t TN (1,000 t TP) to 115,000 t TN (10,500 t TP) in the 1980ties and declined to about 56,750 t TN (2,800 t TP) after 2010. Nutrient concentrations, water transparency (Secchi depth) and chlorophyll-a showed a positive response to the reduced nutrient loads in the Polish eastern lagoon. This was not the case in the German western lagoon, where summer Secchi depth is $0.6 \mathrm{~m}$ and mean chlorophyll-a concentration is four times above the threshold for the Good Ecological Status. Measures to improve the water quality focused until now purely on nutrient load reductions, but the nutrient load targets and Maximal Allowable Inputs are contradicting between EU Water Framework Directive and EU Marine Strategy Framework Directive. According to the HELCOM Baltic Sea Action Plan, the thresholds of the annual riverine nutrient inputs to the lagoon would be about 48,850 t N (1,570 t P). Actions in the river basins that would allow meeting these targets are hardly achievable. Even if the load targets would be fully implemented, they are not sufficient to transfer the lagoon into a non-eutrophic state. The implementation of EU Water Framework Directive is further hampered, as consistent water quality thresholds for the two parts of Szczecin Lagoon are missing. An approach to harmonize them is presented, which incorporates the spatial differences. By implementing consistent water quality targets, Szczecin Lagoon could serve as blueprint for other trans-boundary waters. In the western lagoon, nutrient load reductions in the past decades had no effect on the water quality. High water residence times, frequent sediment resuspension and the missing submerged vegetation inhibit the load reduction effects on the water quality. Internal measures in the western lagoon are necessary, which aim at removing nutrients and increasing water transparency to overcome the hysteresis effect and to initiate a recovery of macrophytes. Cultivation of zebra mussels seems the most promising approach.

Keywords: eutrophication, water quality, nutrient loads, WFD, MSFD, integrated ecosystem modeling, internal measures 


\section{INTRODUCTION}

With an area of $687 \mathrm{~km}^{2}$, Szczecin (Oder-) Lagoon is one of the largest lagoons in Europe. It is located at the border between Germany and Poland (Figures 1, 2) and is divided into Large Lagoon (Polish: Wielki Zalew) and Small Lagoon (German: Kleines Haff). The lagoon is shallow (average depth of $3.8 \mathrm{~m}$ ), has a salinity between 1 and 3 PSU and is connected with the Baltic Sea via three outlets. Large Lagoon, connecting the harbor of Szczecin with the open Baltic, plays an important role for shipping and transportation of goods, therefore a $12 \mathrm{~m}$ deep channel is crossing it (Radziejewska and Schernewski, 2008). With an average water discharge of about $500 \mathrm{~m}^{3} / \mathrm{s}$ and a drainage area of 120,000 km² (Pastuszak, 2012a), the Oder (Odra) River is one of the most important rivers in the Baltic region. It significantly controls water and nutrient budgets of the lagoon (Schernewski et al., 2012b). Ongoing high riverine nutrient loads are responsible for the heavily eutrophied status of the lagoon (Bangel et al., 2004; Schernewski et al., 2008, 2011), indicated among other indicators by low Secchi depths (Figure 2). Szczecin Lagoon is a part of several European conservation-orientated programs, like Natura2000 (Wolnomiejski and Witek, 2013). Because of its size, state of pollution, economic and ecological importance, Szczecin Lagoon has received a lot of scientific attention. It plays an important role as converter and sink for nutrients and pollutants effecting also water quality of the Baltic Sea (Radziejewska and Schernewski, 2008).

Szczecin Lagoon is managed within EU's Water Framework Directive (WFD; WFD, 60EC), which aims to establish a "Good Ecological Status" (GES) in all surface waters. GES is defined as a $50 \%$ deviation from "reference conditions" that describe a "high status with no, or very minor disturbance from human activities" (CIS-COAST, 2003). The WFD takes into account that coastal waters are controlled by nutrient loads from river basins, therefore it recommends comprehensive river basin management plans, linking coastal water objectives and measures in the catchments. In the Baltic Sea, the WFD is complemented by the HELCOM Baltic Sea Action Plan (BSAP), a comprehensive program to restore GES in the Baltic marine environment (HELCOM, 2007, 2013b). HELCOM BSAP can be seen as the regional implementation of the EU Marine Strategy Framework Directive (MSFD, 2008/56/EC). HELCOM BSAP has several operational ecological targets with respect to eutrophication, especially nutrient concentrations close to the natural level, satisfactory water transparency or natural blooms of algae. To achieve the targets, the Baltic countries agreed (beside other obligations) on Maximum Allowable Inputs of nutrients (MAI) and reduction targets in order to reach GES in the Baltic Sea (HELCOM, 2013a,c).

One problem in the Oder River and Szczecin Lagoon system is that coherent GES targets and MAI do not exist (Pastuszak et al., 2003, 2005, 2012a,b; Schernewski et al., 2011; Pastuszak and Witek, 2012a,b). For Small Lagoon, nutrient target threshold concentrations calculated by Brockmann et al. (2005), were far too ambitious to be reached even with an highflying river basin management (Schernewski et al., 2008, 2012b; Nausch et al., 2011). Furthermore, the nutrient targets did not match with chlorophyll-a, although closely linked. Therefore, Schernewski et al. (2015) carried out a full re-calculation of target concentrations for nitrogen, phosphorus and chlorophyll-a in all German coastal waters of the western Baltic Sea, which included a harmonization of water quality targets of waters managed by WFD and MSFD. Then, MAI and target concentrations in rivers for the German Baltic catchments were calculated, so that water quality targets were fulfilled on average. Although, this approach was a major step forward, it has several weaknesses in the case of Szczecin Lagoon, mainly: (a) thresholds are only provided for Small Lagoon (on WFD water type level), whereas for the Polish part harmonized thresholds need to be complemented. Most parameters in the lagoon show strong spatial gradients, therefore, spatially refined analysis and thresholds are required; (b) the German GES thresholds were derived from the state of 1880 , by enhancing the estimated pre-industrial concentrations of chlorophyll-a, TN and TP by 50\% (Schernewski et al., 2015). This approach allowed to derive consistent thresholds for all coastal and marine waters of the German Baltic Sea. But it stays an open questions, if the targets are reachable in a naturally eutrophic system; (c) water quality improvements via river basin nutrient load reductions usually take decades until they are fully visible (Grimvall et al., 2000; Oenema et al., 2005). Moreover, against the background of ongoing climate change, it is uncertain whether present water quality targets are suitable for future climate (Friedland et al., 2012; Meier et al., 2012a,b, 2014; BACC, 2015; Michalak, 2016), or if an adaptation will be necessary; (d) present targets focus on nutrients, but in naturally eutrophic systems, like Szczecin Lagoon, it is questionable if GES, with respect to biological parameters, can be achieved by a nutrient management alone. At least, more biologically related indicators and thresholds, like water transparency (Secchi depth) or occurrence of submerged macrophytes (Borja et al., 2012), should be considered; (e) there exists no spatial-explicit approach to link MAI with GES-targets on the scale of single water bodies, instead both are integrated over larger regions, e.g., the subbasins used by HELCOM, or the entire south-western Baltic Sea at Schernewski et al. (2015).

The objectives of our study are to: (i) give a comprehensive overview about the development of external nutrient loads into Szczecin Lagoon between 1880 and today; (ii) document resulting changes of major water quality parameters in the lagoon between 1880 and today; (iii) show spatial and interannual variability of parameters within the two parts of the lagoon; (iv) analyze the re-eutrophication process and hysteresis effects; (v) test the hypothesis that management actions in the river basins are sufficient to achieve the GES thresholds; and (vi) present the state of and discuss the consequences for water quality objectives and policy implementations.

\section{METHODS}

\subsection{Nutrient Loads to Szczecin Lagoon}

Szczecin Lagoon's nutrient budget is dominated by waterborne nutrient loads from Oder, Peene, Uecker, and Zarow, with Oder accounting for more than $90 \%$ of the total waterborne 
loads (Wielgat, 2002). Contribution of atmospheric deposition of nitrogen $(\mathrm{N})$ and phosphorus $(\mathrm{P})$ is marginal, as it constitutes $1 \%(\mathrm{~N})$ and $0.2 \%(\mathrm{P})$, respectively to overall loads. Loads from point sources play a minor role, being strongly reduced in the

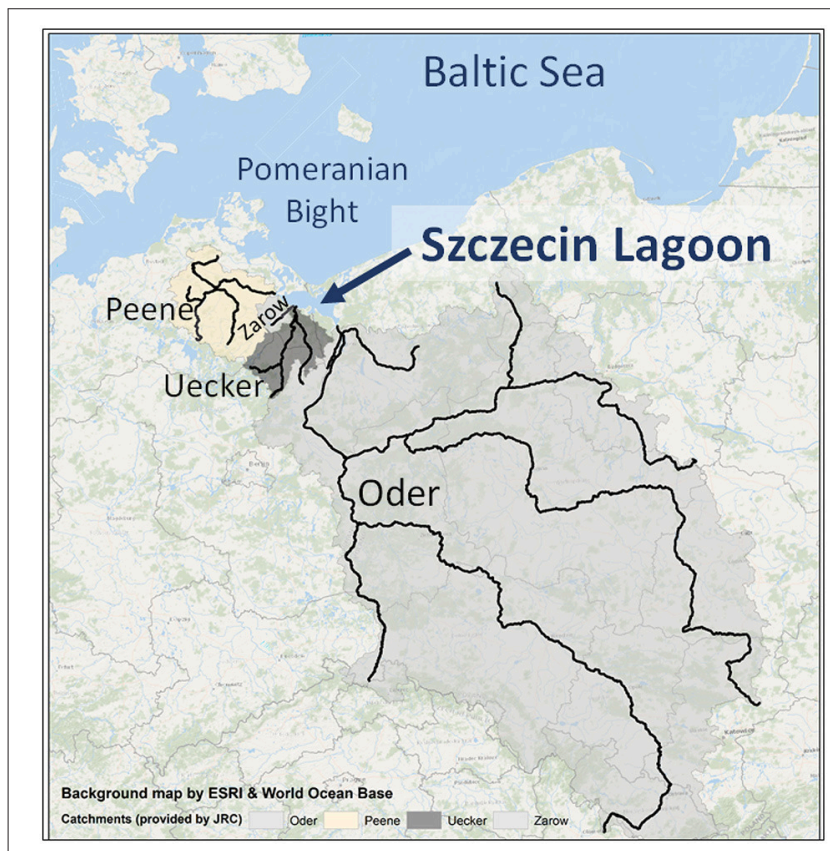

FIGURE 1 | Catchment areas of the main rivers entering Szczecin Lagoon. 1990ties (Wielgat, 2002). Although lower, German waterborne nutrient loads impact especially Small Lagoon, where only approximately $20 \%$ of the Oder nutrient loads end up (Wielgat, 2002). Since late 1970ties, the German waterborne loads have been regularly monitored, nowadays being a part of the German implementation strategy of the WFD. Nutrient concentrations are usually measured twice a month (Bachor, 2005), likewise the freshwater runoff, which is partly also computed automatically on a daily basis. Monitoring of nutrients in Oder River is conducted in Krajnik Dolny (Kowalkowski et al., 2012; Pastuszak, 2012a,b) at least once a month (Jadczyszyn and Rutkowska, 2012). Riverine data collection started in 1988 and has been elaborated by Pastuszak et al. (2018). Reconstructions prior 1988 were used from Behrendt et al. (2008) and from Baltic Nest Institute (Wulff et al., 2013).

Environmental data, such as riverine nutrient concentrations and loads, often exhibit substantial natural variability caused by weather conditions at, or prior to the sampling occasion. The Partial Mann-Kendall test (Libiseller and Grimvall, 2002) was used to detect long-term changes in solute concentrations and flow-normalized loads. The test has its methodological basis in the seasonal Mann-Kendall-test (Hirsch and Slack, 1984), which has been used to detect temporal trends in environmental data, with the difference that water discharge is included as explanatory variable. The trend assessment (Table 1) was performed by comparing the calculated loads with the flow-normalized loads, based on a semi-parametric regression method (Stålnacke and Grimvall, 2001; Hussian et al., 2004). This normalization method aims at removing the natural fluctuations in loads and concentrations caused

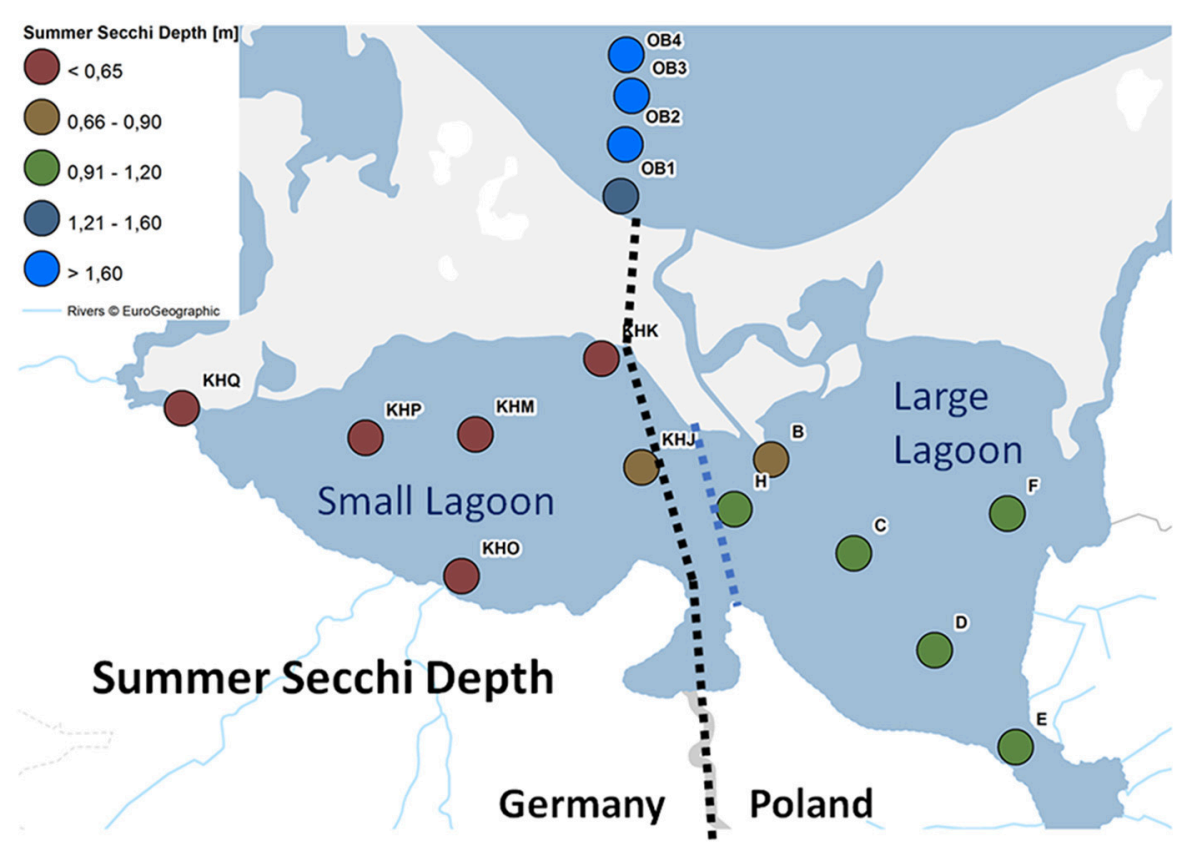

FIGURE 2 | Spatial distribution of water quality monitoring stations in Large Lagoon, Small Lagoon and Southern Pomeranian Bight color-coded by the mean Summer Secchi depth. 
TABLE 1 | Flow-normalized loads to Szczecin Lagoon for the reference period (1997-2003) and recent times (2010-2014), values in brackets indicate the loads without flow-normalization.

\begin{tabular}{|c|c|c|c|c|c|c|c|c|c|}
\hline \multirow[t]{2}{*}{ River } & \multirow[t]{2}{*}{ Years } & \multicolumn{3}{|c|}{ TN [t/a] } & \multicolumn{3}{|c|}{$\mathrm{TP}[\mathrm{t} / \mathrm{a}]$} & \multicolumn{2}{|c|}{ Runoff $\left[\mathrm{m}^{3} / \mathrm{s}\right]$} \\
\hline & & $\begin{array}{l}1997- \\
2003\end{array}$ & $\begin{array}{c}2010- \\
2014\end{array}$ & $\begin{array}{c}p- \\
\text { value }\end{array}$ & $\begin{array}{l}1997- \\
2003\end{array}$ & $\begin{array}{c}2010- \\
2014\end{array}$ & $\begin{array}{c}p- \\
\text { value }\end{array}$ & Mean & $\begin{array}{c}p- \\
\text { value }\end{array}$ \\
\hline Uecker & 1978-2015 & 892 & 801 & $0.012^{* *}$ & 28 & 37 & $0.001^{* *}$ & 7.6 & 0.393 \\
\hline Zarow & 1978-2015 & 418 & 319 & 0.436 & 9 & 13 & 0.309 & 2.4 & $0.031^{* *}$ \\
\hline Peene & 1978-2015 & 3,294 & 2,869 & 0.555 & 69 & 83 & $0.000 * *$ & 21.8 & $0.036 * *$ \\
\hline $\begin{array}{l}\text { German } \\
\text { rivers }\end{array}$ & 1978-2015 & $\begin{array}{c}4,605 \\
(3,891)\end{array}$ & $\begin{array}{c}3,989 \\
(4,456)\end{array}$ & 0,297 & 106 & $\begin{array}{c}133 \\
(132)\end{array}$ & $0.000^{* *}$ & 31.8 & $0.051^{*}$ \\
\hline Oder & 1988-2014 & $\begin{array}{c}57,220 \\
(66,500)\end{array}$ & $\begin{array}{c}52,762 \\
(61,950)\end{array}$ & $0.000^{* *}$ & $\begin{array}{c}4,116 \\
(4,509)\end{array}$ & $\begin{array}{c}2,675 \\
(3,054)\end{array}$ & $0.000^{* *}$ & 504.3 & 0.307 \\
\hline
\end{tabular}

** Statistically significant downward $(p<0.05)$

* Downward but not statistically significant $(0.05<p<0.1)$

P-values of the long-term trends were computed using the flow-normalized input data, asterisks indicating the degree of statistical significance (no asterisk = no significant change).

by variability in water discharge or other weather-dependent variables, so that the loads at "normal" water discharge are estimated. Such removal or reduction of irrelevant variation in the collected data can help to clarify the impact of human pressures on the environment (here, the impact on riverine loads of nutrients). It has also been shown that semiparametric normalization models were almost invariably better than ordinary regression models (Hussian et al., 2004).

Maximum Allowable Inputs (MAI) by HELCOM BSAP (HELCOM, 2013a,c) were downscaled for the single rivers from the national reduction schemes. Additionally, Poland and Germany have target concentrations defined within the national implementation strategies of EU's WFD (WFD, 60EC). The German WFD target concentrations are $2.6 \mathrm{mg}$ TN/l and $0.1 \mathrm{mg}$ TP/l (BLANO, 2014). Poland uses differentiated target concentrations (Garcia et al., 2012) for large lowland rivers, like Oder, (type 21; $4.0 \mathrm{mg} \mathrm{TN} / \mathrm{l}, 0.29 \mathrm{mg} \mathrm{TP} / \mathrm{l}$ ) and small rivers directly feeding the coastal zone, like the German rivers entering Szczecin Lagoon (type 22; $2.7 \mathrm{mg}$ TN/l, $0.32 \mathrm{mg} \mathrm{TP} / \mathrm{l})$.

To estimate the pre-industrial nutrient loads, the GIS (Geographical Information System) based catchment model MONERIS (MOdeling Nutrient Emissions in RIver Systems) was applied (Behrendt and Dannowski, 2005; Venohr et al., 2011). It was adjusted to present observations for Oder (Kowalkowski and Buszewski, 2006; Schernewski et al., 2008; Kowalkowski et al., 2012) and the German catchment area (BLANO, 2014; Ackermann et al., 2016). The simulated pre-industrial loads (referring to 1880) and a summary of underlying assumptions are published for German catchment (Hirt et al., 2014) and for Oder (Gadegast et al., 2012, 2014; Gadegast and Venohr, 2015). Thereby Gadegast and Venohr (2015) gave only the mean TN concentrations (1.6 mg TN/l for Oder; $1.0 \mathrm{mg} \mathrm{TN} / \mathrm{l}$ for Peene and Uecker; $0.6 \mathrm{mg} \mathrm{TN} / \mathrm{l}$ for Zarow), which were upscaled to annual loads using the recent runoffs.

\subsection{Water Quality of Szczecin Lagoon}

In Small Lagoon, eutrophication parameters are gathered monthly at three stations (KHJ, KHP, and KHM; Figure 2); additionally, observations are carried out near the bottom at station KHM. Until 2006, three more stations (KHO, KHK, and KHQ) were monitored. The same focusing at the most relevant stations took place in Large Lagoon, where data are collected from March to November at stations C, E, and H (Figure 2), while stations B, D and F were sampled only until 2006. First observations and macrophyte mappings in Szczecin Lagoon were carried out in the 1880s (Brandt, 1894/96). The regular Secchi depth monitoring started in the 1960ties (Baudler et al., 2012) and was afterwards supplemented by additional parameters covering nearly the last 50 years. A first data set was compiled by Bangel et al. (2004) and extended using public available data from LUNG (State Agency for Environment, Nature Conservation and Geology Mecklenburg-Vorpommern) and annual reports on the nature of German - Polish border waters published at WasserBLIcK ${ }^{1}$.

Threshold determining the "Good Environmental State" (GES) in Small Lagoon are set for summer Secchi depth (1.7 m; Sagert et al., 2008); summer chlorophyll-a (14.3 $\mu \mathrm{g} / \mathrm{l}$; BLANO, 2014; Schernewski et al., 2015) and nutrient concentrations (2.3 $\mu \mathrm{mol} / \mathrm{l} \mathrm{TP} ; 38.1 \mu \mathrm{mol} / 1 \mathrm{TN}$; BLANO, 2014; Schernewski et al., 2015). The latter were derived by using the Integrated Modeling Approach (Schernewski et al., 2015), which combined recent observations with model simulations to estimate the preindustrial state (1880) serving as reference state. GES threshold concentrations were derived by enhancing the reference concentration with 50\% (CIS-COAST, 2003).

\subsection{Modeling of Water Quality Parameters}

Any 3-d model of Szczecin Lagoon must reflect the strong spatial gradients, but also the exchange with the open Baltic

\footnotetext{
${ }^{1}$ https://www.wasserblick.net/servlet/is/34786/
} 
Sea (Pomeranian Bight), which takes place via three narrow outlets (Swina, Peenestrom, and Dziwna; Figure 2). So does the model system ERGOM-MOM (Schernewski et al., 2015), covering the entire Baltic Sea. It consists of the ocean model MOM (Pacanowski and Griffies, 2000) and the pelagic ecosystem model ERGOM that is suitable for applications in the Baltic Sea (Eilola et al., 2011; Friedland et al., 2012). It has a horizontal resolution of 1 nautical mile in the western Baltic Sea and the vertical water column is sub-divided into layers with a thickness of $2 \mathrm{~m}$. In order to adjust the simulated water exchange between Szczecin Lagoon and the Pomeranian Bight on this coarse grid to realistic levels, the depth of Swina had to be reduced to $5 \mathrm{~m}$.

The biogeochemical module ERGOM (Neumann, 2000; Neumann et al., 2002; Neumann and Schernewski, 2008) consists of three dissolved inorganic nutrients (nitrate, ammonium and phosphate), three functional phytoplankton groups (large and small cells, nitrogen fixers), fast-sinking dead organic material and a bulk zooplankton, which is grazing on the phytoplankton. Detritus is partly mineralized back into ammonium and phosphate, while the other portion accumulates at the sea bottom, where it is subsequently buried, mineralized or resuspended. All state variables are linked via advection-diffusion equations to the circulation model. Using stoichiometric ratios, the production and consumption of oxygen is calculated from all biogeochemical processes. Vice versa, the oxygen conditions determine, whether phosphate is bound to iron in the sediment (oxic situation) or is released (during anoxia). To evaluate the quality of the model outputs the method of Edman and Omstedt (2013) and Meier et al. (2018) was applied (Figure 8), by combining the coefficient of correlation $R$ and a cost function $C$, which is the mean model bias normalized by the standard deviation of the observations.

To study the water exchange of Small Lagoon, a highresolution model system was set up, using the coastal ocean model GETM (Burchard and Bolding, 2002; Klingbeil and Burchard, 2013) instead of MOM. The refined model set-up covered Szczecin Lagoon and the surrounding waters with a horizontal resolution of $150 \mathrm{~m}$ (approximately 33,000 horizontal grid cells instead of 228 at ERGOM-MOM) and 20 vertical layers that adapt toward stratification (Hofmeister et al., 2010; Gräwe U, 2015). Following previous approaches (Gräwe et al., 2012; Schernewski et al., 2012a; Schippmann et al., 2013a,b), every day ten individual particles were released and followed until they either left Small Lagoon (to Peenestrom or Large Lagoon) or they reached the maximum age of 60 days. The particles represent inert substances driven exclusively by advection (Oliveira and Baptista, 1997). The horizontal diffusivity was taken into account using the random walk method, described by stochastic differential equations of motion (Heemink, 1990).

The model system ERGOM-MOM was further applied to two scenario simulations. To simulate the pre-industrial state (averaged for the period 1880 to 1885, after a spin-up of 25 years with a coarse model and additionally five years with ERGOMMOM), the needed waterborne loads were taken for the German catchment and Oder river from MONERIS (Gadegast et al., 2012; Hirt et al., 2014). For the remaining catchments, the atmospheric deposition and weather forcing, reconstructions (Gustafsson et al., 2012; Ruoho-Airola et al., 2012; Schenk and Zorita, 2012) were used. For the future scenario, a transient simulation of the 21st century was conducted, assuming a moderate climate change by applying scenario RCP 4.5 (Pachauri et al., 2014) and that the MAI from BSAP (HELCOM, 2013b,c) are Baltic-wide fully implemented. The water temperature increase until the end of 21 st century is with approximately $1.5 \mathrm{~K}$ quite low compared to most other studies (BACC, 2015). For the later calculations, the model results at the end of 21st century (averaged for 2080-2100) were used.

\section{RESULTS}

\subsection{Nutrient Loads to Szczecin Lagoon-Development and Targets}

Annual estimated riverine loads to Szczecin Lagoon during 1997 to 2003 (reference period of HELCOM BSAP) were approximately 70,400 t TN and 4,600 t TP (flow-normalized: 61,825 t TN and 4,222 t TP; Figure 3; Table 1). In recent years (average between 2010 and 2014), the loads dropped to approximately 66,400 t TN/a and 3,200 t TP/a (flow-normalized: $56,750 \mathrm{t} \mathrm{TN} / \mathrm{a}$ and 2,790 t TP/a). The flow-normalized TN loads reached their maximum in the early 1990ties (approximately $85,000 \mathrm{t} \mathrm{TN} / \mathrm{a}$ ), while flow-normalized TP loads peaked at the end of 1980ties (approximately 8,500 t TP/a). The reconstructed loads were highest in 1977 and 1981 with up to $115,000 \mathrm{t} \mathrm{TN} / \mathrm{a}$ and $10,500 \mathrm{t} \mathrm{TP} / \mathrm{a}$, when runoff was $870 \mathrm{~m}^{3} / \mathrm{s}$ (1977) and $841 \mathrm{~m}^{3} / \mathrm{s}$ (1981) substantially above the long term average $\left(504 \mathrm{~m}^{3} / \mathrm{s}\right.$; Table 1). Using the catchment model MONERIS, the estimated pre-industrial TN loads differ substantially (between 14,100 and 26,400 t TN/a; Table 2). TP loads increased from approximately 1,000 t TP/a in 1880 (Table 2) already strongly until 1960, where they were on the same level as recently (Figure 3). The TN loads of 1960 were still near to the upper estimate for the historical levels, before they increased rapidly (Figure 3).

Nearly all rivers show a significant decrease of flownormalized TP loads, for TN loads this is only the case for Oder and Uecker (Table 1). The German rivers had further a decreasing trend of the freshwater runoff (Table 1). The loads showed the strongest decrease in the early 1990ties, while since 1995 the flow-normalized German TP loads stayed on the same level (approximately $100 \mathrm{t} \mathrm{TP} / \mathrm{a}$ ), except 2011. The flow-normalization has thereby only a minor influence on the German TP loads (Figure 3), while it smoothed the TN loads, revealing that there was nearly no decrease (Figure 3). The flownormalization resulted thereby in a smaller annual load for Oder in 15 of 27 years for TN (17 of 27 for TP) and for the German rivers in 20 of 37 years for TN ( 19 of 37 for TN).

Applying the flow-normalization led to lower nutrient loads from Oder for the reference period and recent years, while the German flow-normalized loads are higher in both period. But the method worked well to reduce the impact of floods on the loads (Figure 3). In 2010, strong rainfalls resulted in an extremely high outflow (up to $1,400 \mathrm{~m}^{3} / \mathrm{s}$ in June) and extraordinary high loads $(91,000 \mathrm{t} \mathrm{TN} / \mathrm{a}$ and 4,100 t TP/a), while this peaks are not visible in the flow-normalized loads. But also some exceptional years 


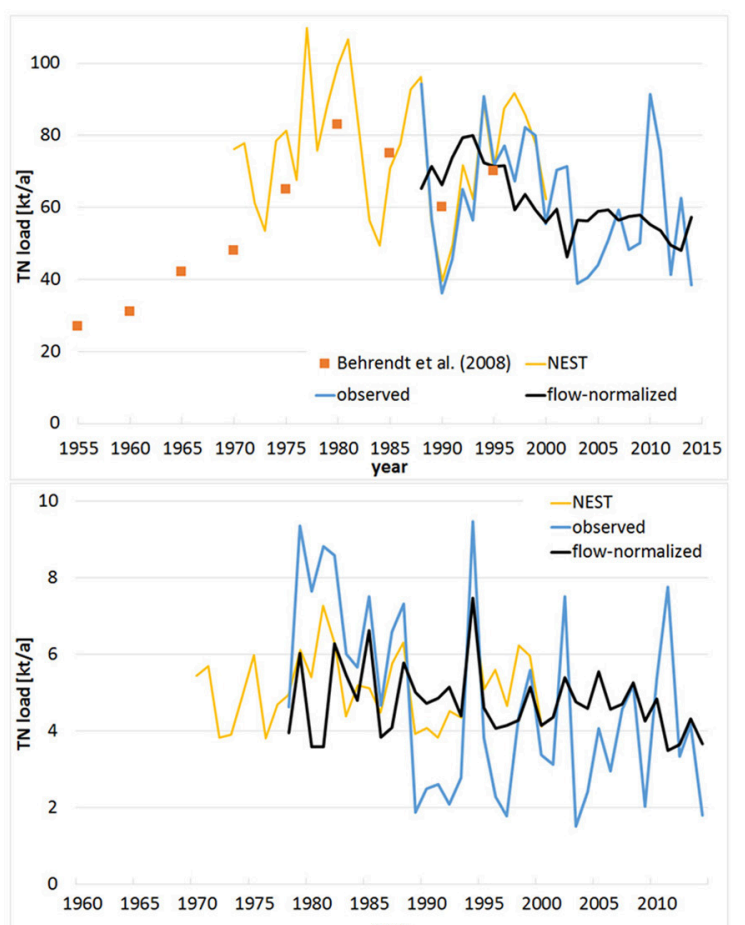

year

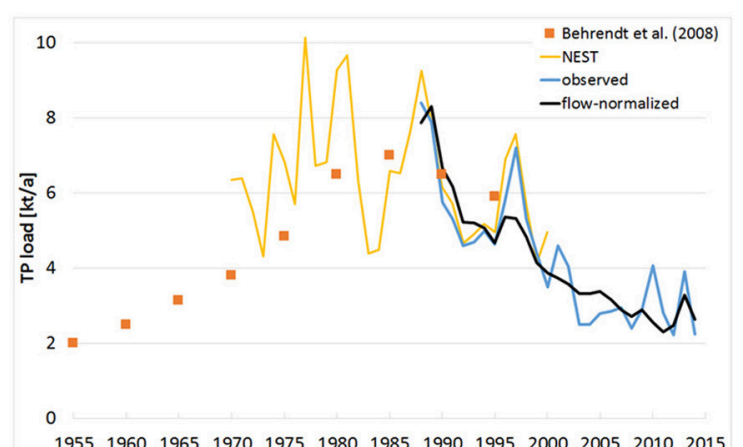

$\begin{array}{llllllllll}19551960 & 1965197019751980 & 1985 & 1990 & 1995 & 2000 & 2005 & 2010 & 2015\end{array}$
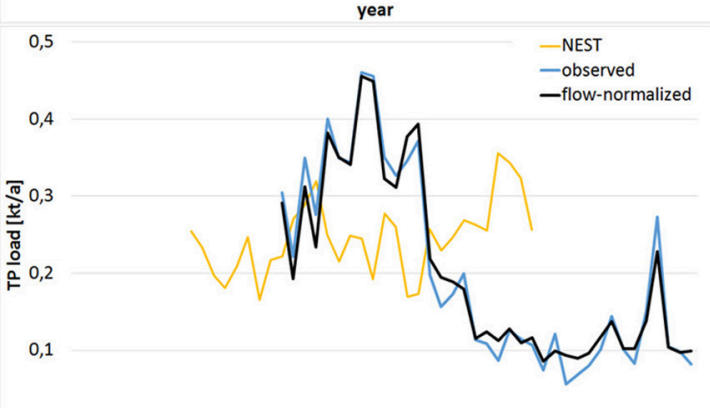

$\begin{array}{lllllllllll} & 0 \\ 1960 & 1965 & 1970 & 1975 & 1980 & 1985 & 1990 & 1995 & 2000 & 2005 & 2010\end{array}$ year

FIGURE 3 | Annual total nitrogen (TN) and total phosphorus (TP) loads discharged by Oder (Upper) and summed for Peene, Uecker and Zarow (Lower) based on observations (blue) and flow-normalization (black); supplemented by reconstructed loads from Baltic Nest Institute (yellow; Wulff et al., 2013) and Behrendt et al., 2008 (orange, only for Oder).

TABLE 2 | Flow-normalized loads to Szczecin Lagoon for the reference period of BSAP (1997-2003) and load targets according to HELCOM Baltic Sea Action Plan (HELCOM, 2013b); loads calculated with adoption of the Polish WFD target (Garcia et al., 2012) and the German WFD-target (BLANO, 2014); estimated pre-industrial loads from catchment model MONERIS.

\begin{tabular}{|c|c|c|c|c|}
\hline & \multicolumn{2}{|c|}{ Sum of German rivers } & \multicolumn{2}{|c|}{ Oder } \\
\hline & TN load [t/a] & TP load [t/a] & TN load [t/a] & TP load [t/a] \\
\hline MAI BSAP & 4,227 & 84 & 44,631 & 1,482 \\
\hline Polish WFD target & 2,714 & 312 & 63,661 & 4,615 \\
\hline Pre-industrial (Gadegast et al., 2012; Hirt et al., 2014) & 718 & 19 & 13,425 & 950 \\
\hline
\end{tabular}

remained, e.g., in 2014 Oder runoff was extremely low $\left(400 \mathrm{~m}^{3} / \mathrm{s}\right)$, resulting in an increase of flow-normalized TN loads compared to previous years. Vice versa, the flow-normalized TP loads had a recent peak in 2013, when runoff was very high $\left(626 \mathrm{~m}^{3} / \mathrm{s}\right)$. In summer 2011 very strong rainfalls occurred, resulting in extremely high runoff combined with high TP concentrations due to the erosion in agricultural areas, especially in the Uecker catchment. As a consequence, monthly flow-normalized TP load was $13.7 \mathrm{t}$ in August 2011, which is one order of magnitude above the long-term August average (1.5 t).

Downscaling the Maximal Allowable Inputs (MAI) from HELCOM BSAP, leads to reduction needs of $8.2 \%(21.1 \%)$ and 22\% (64\%) for German and Polish waterborne TN (TP) loads compared to the reference period. The MAI of Oder (on basis of the flow-normalized loads; Table 2) are then approximately 44,630 t TN/a (1,482 t TP/a) and for the German tributaries 4,230 t TN/a (80 t TP/a; Figure 3). After 2010, only Zarow fulfilled the TN target. None of the rivers was below the TP MAI of HELCOM BSAP. Adopting the different WFD threshold concentrations together with the average annual water discharges, MAI arising from the WFD assumptions are substantially differing from each other and also from the HELCOM MAI (Table 2). The German WFD target results in an allowable TN load of approximately 2,600 $\mathrm{t}$ TN/a for the 
German rivers, what means an additional TN reduction need of $30 \%$ compared to BSAP and $4 \%$ compared to the Polish WFD target. The German WFD TP target is substantially below than the Polish one, but less strict than BSAP and was almost equal to the reference loads. Assuming the German WFD target for the Oder, corresponds to an annual TN-MAI of approximately 41,400 t TN (Table 2). This would mean an additional reduction need of $7.3 \%$ compared to BSAP and would be a substantial tightening (35\%) compared to the present Polish WFD target.

\subsection{Water Quality in Szczecin Lagoon-Development and Targets}

Secchi depth (SD), as well as near surface concentrations of chlorophyll-a (Chl-a), total nitrogen (TN) and total phosphorus
(TP) are shown for Small Lagoon (represented by station KHM) and Large Lagoon (station C) in Figure 4. Throughout the study period, SD was in Large Lagoon always higher than in Small Lagoon, while Chl-a concentrations are substantially lower than in Small Lagoon. Until the middle of the 1990ties, Chla was in the same range for both parts. Then, it decreased by half in Large Lagoon (Figure 4). This decrease of Chl-a is significant for the whole time period, but also for the recent years (Table 3). It is strongly correlated with the reduced riverine TP loads $\left(R^{2}=0.85\right.$; Figure 5), but only slightly with the TN loads $\left(R^{2}=0.14\right.$; Figure 5). In Small Lagoon, concentrations of Chl-a dropped in the 1980ties. Afterward, they remained on the same level (Figure 4) unaffected from the decreased nutrient loads (Figure 6). No significant trend was found, instead the $p$-value even increased for recent years (Table 3).

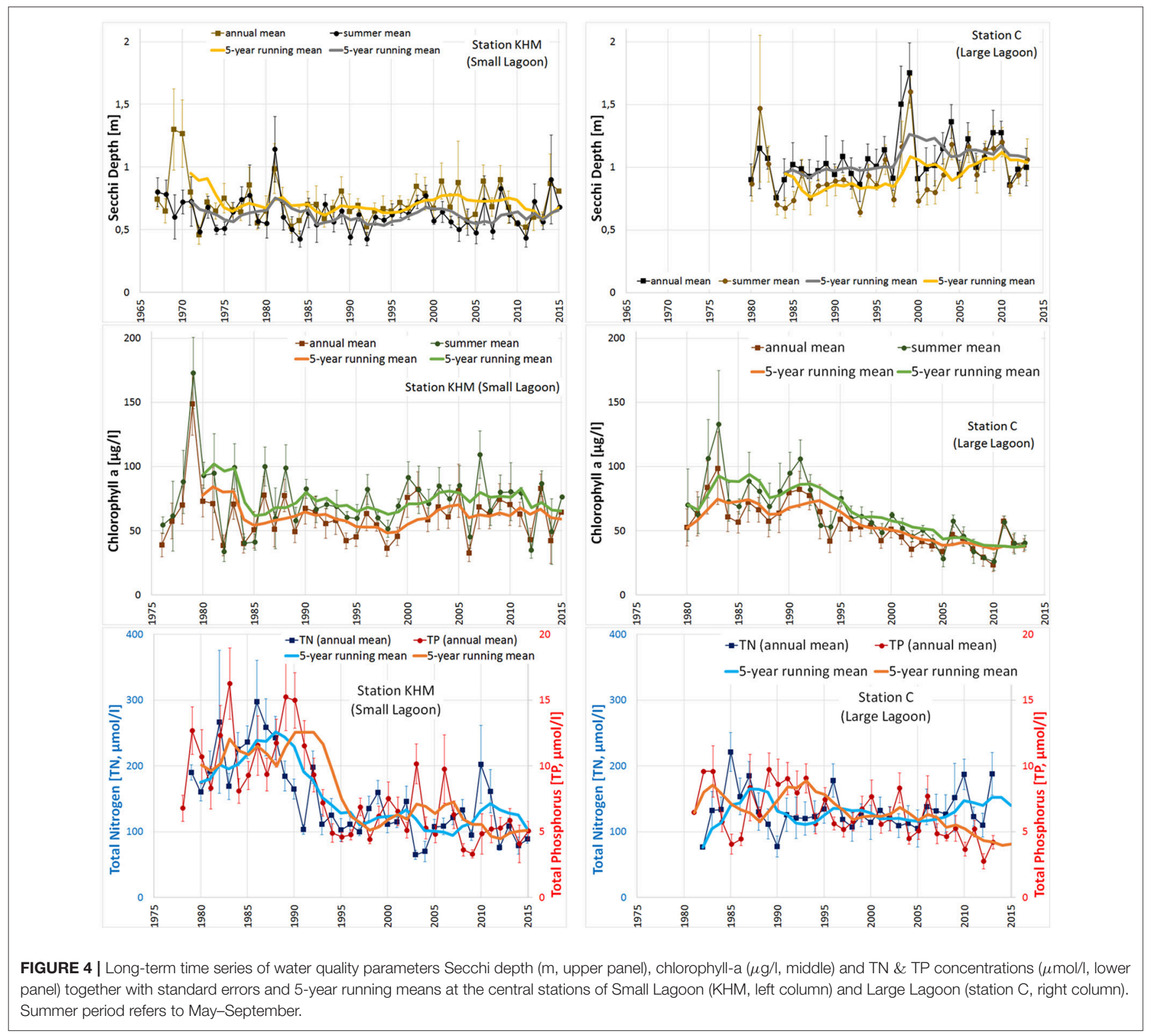


TN and TP concentrations in Small Lagoon decreased from the maximal concentration in mid-1980s of approximately $300 \mu \mathrm{mol} \mathrm{TN} / \mathrm{l}(13 \mu \mathrm{mol} \mathrm{TP} / \mathrm{l})$ to $100-150 \mu \mathrm{mol} \mathrm{TN} / \mathrm{l}(5-$ $7 \mu \mathrm{mol} \mathrm{TP} / \mathrm{l}$ ) mid of the 1990ties, resulting in a significant downward trend, which can not be found for recent years (Table 3). In Large Lagoon, TP concentration showed a continuous declining trend since its peak around 1990, resulting in significant downward trend (Table 3). This decreasing trend is strongly correlated to the riverine TP loads $\left(R^{2}=0.66\right)$. TN concentrations declined between 1985 and 1990, remained quite constant afterwards and started to increase after 2005 (Figure 4), unaffected of the decreasing TN loads, so that no downward trend was found (Table 3).

In Small Lagoon, the GES thresholds are most strongly violated in the case of Chl-a. The present state is five times the target value (Figures 5, 7). But TN and TP are also

TABLE $3 \mid P$-values of the long-term decreasing trend for water quality parameters observed at Station C (Large Lagoon) and KHM (Small Lagoon) computed for either the whole time period (see Figure 4) or since 1995.

\begin{tabular}{lllll}
\hline & \multicolumn{2}{c}{ Station C } & \multicolumn{2}{c}{ KHM } \\
\cline { 2 - 5 } & $\begin{array}{l}\text { Full } \\
\text { period }\end{array}$ & $\begin{array}{l}\text { Since } \\
\mathbf{1 9 9 5}\end{array}$ & $\begin{array}{l}\text { Full } \\
\text { period }\end{array}$ & $\begin{array}{l}\text { Since } \\
\mathbf{1 9 9 5}\end{array}$ \\
\hline Chlorophyll a (annual mean) & $0.000^{* *}$ & $0.007^{* *}$ & 0.305 & 0.761 \\
Chlorophyll a (Summer mean) & $0.000^{* *}$ & $0.001^{* *}$ & 0.217 & 0.476 \\
Secchi Depth (annual mean) & $0.064^{*}$ & 0.787 & 0.786 & 0.472 \\
Secchi Depth (Summer mean) & $0.064^{*}$ & 0.324 & 0.676 & 0.304 \\
Total nitrogen (annual mean) & 0.316 & 0.844 & $0.000^{* *}$ & 0.281 \\
Total phosphorus (annual mean) & $0.001^{* *}$ & $0.004^{* *}$ & $0.000^{* *}$ & 0.172 \\
\hline
\end{tabular}

** Statistically significant $(\mathrm{p}<0.05)$

*Downward (upward for Secchi Depth) but not statistically significant $(0,05<p<0,1)$

Asterisks indicate the degree of statistical significance (no asterisk = no significant change). more than twice the threshold concentrations. Transferring the target setting approach from Small Lagoon to the Polish part allows to derive harmonized targets, which include the spatial characteristics. Therefore, the present observed state is transferred by the ratio between simulated pre-industrial and present state to its reference state. Target concentrations are derived by enhancing the reference state with $50 \%$. With $17.3 \mu \mathrm{g} \mathrm{Chl}-\mathrm{a} / \mathrm{l} ; 42.5 \mu \mathrm{mol} \mathrm{TN} / \mathrm{l} ; 2.4 \mu \mathrm{mol} \mathrm{TP} / \mathrm{l}$ the derived targets would be slightly above the ones for Small Lagoon

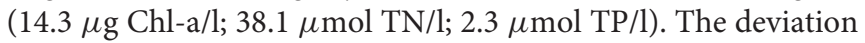
between present state and targets for TN and TP concentrations are quite the same as in Small Lagoon, while Chl-a in Large Lagoon would be twice the target (Figure 7). Extending the target setting approach also to $\mathrm{SD}^{2}$, would result in target values of $2.87 \mathrm{~m}$ (Large Lagoon) and $1.97 \mathrm{~m}$ (Small Lagoon). This target thresholds would be approximately three times the present state.

\subsection{Modeling of Water Quality Parameters}

Using observations from all available stations in Szczecin Lagoon and from the Southern Pomeranian Bight (Figure 2), the model skill of ERGOM-MOM was calculated for surface Chla and dissolved nutrients (DIN, DIP), as well as for the near bottom values of salinity and oxygen (Figure 8). Following the classification of Omstedt et al. (2012), simulated surface DIN, bottom oxygen and salinity are good or acceptable for nearly all stations. Modeled surface Chl-a and DIP suffer from the low correlation coefficients, although the normalized biases are in the same range like for the other quantities. The single stations of the different regions cluster strongly. The strongest deviation at Chl-a in Small Lagoon occurred thereby in autumn and winter, so that the derived water quality targets for summer Chl-a are not impacted (Figure 7). But their too low concentration has a strong impact on the DIP concentrations, as phytoplankton is missing to bind DIP. On the other hand, the increase of DIP concentrations in late summer after the depletion in spring and early summer

\footnotetext{
${ }^{2}$ Schernewski et al. (2015) did the target setting only for Chl-a, TN and TP.
}

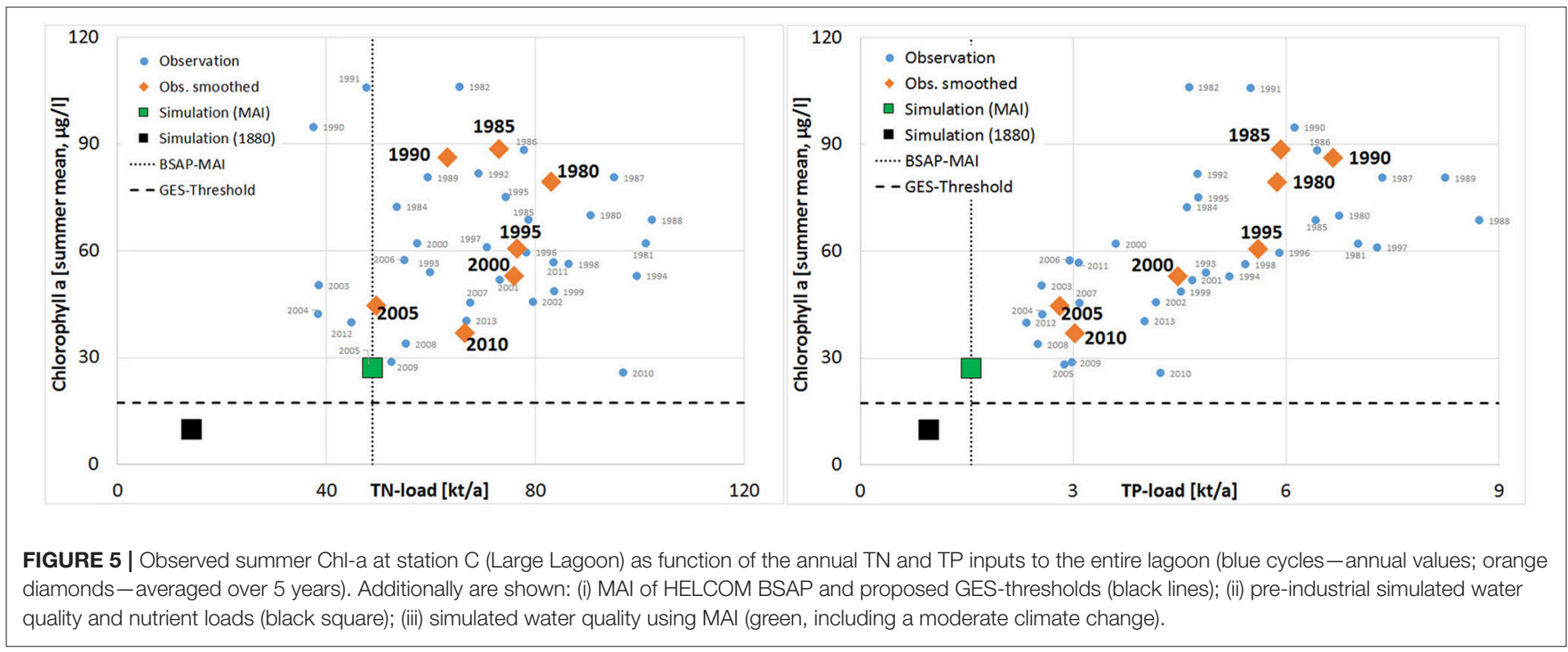



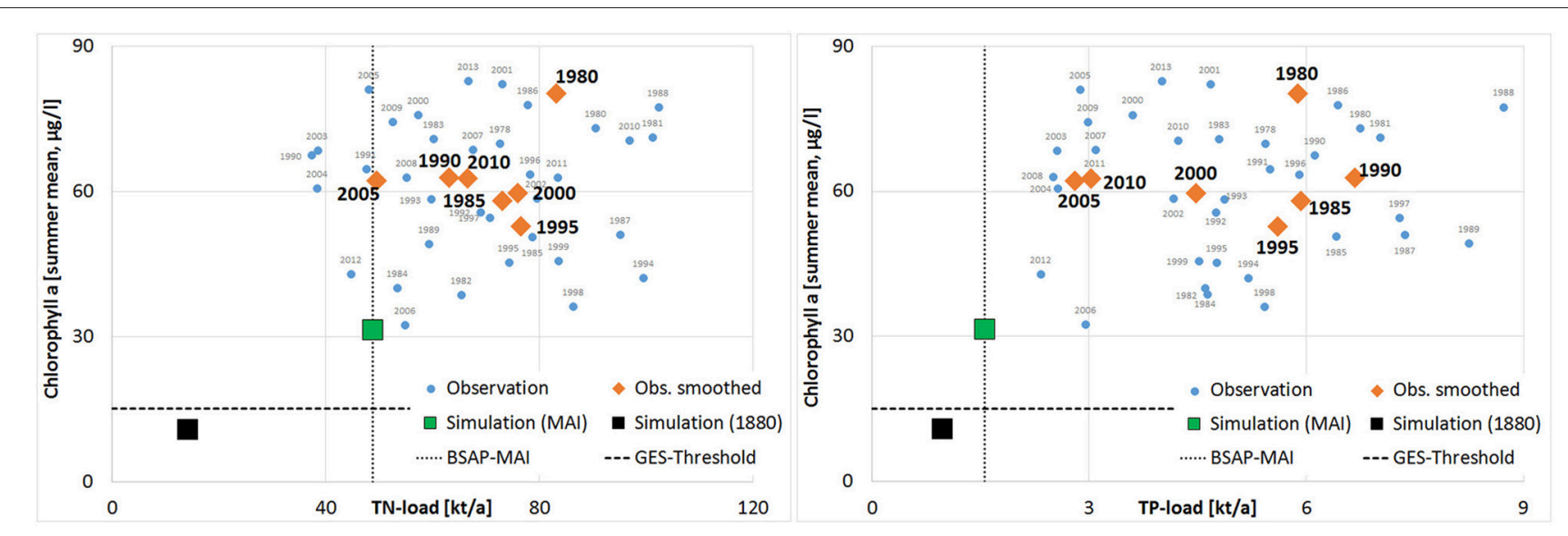

FIGURE 6 | Observed summer Chl-a at station KHM (Small Lagoon) as function of the annual TN and TP inputs to the entire lagoon (blue cycles-annual values; orange diamonds - averaged over 5 years). Additionally are shown: (i) MAI of HELCOM BSAP and proposed GES-thresholds (black lines); (ii) pre-industrial simulated water quality and nutrient loads (black square); (iii) simulated water quality using MAl (green, including a moderate climate change). Note that Chl-a of 1979 (149 $\mu \mathrm{g} / \mathrm{l}$ ) was excluded.

starts approximately 1 month earlier in the observations then in the model simulation, worsening the correlation.

While the simulation covering the pre-industrial period was used to derive the water quality thresholds, the transient simulation of the 21 st century was run to test the Baltic-wide implementation of MAI from HELCOM BSAP. In both parts of Szczecin Lagoon, none of the GES thresholds is met by the scenario simulation (Figure 7). Especially, the simulated Chl-a and TN concentrations are strongly above the thresholds, while TP targets are almost met. In both simulations, the simulated Chl-a concentrations are quite the same for both parts of Szczecin Lagoon, dissipating the spatial differences for the present state seen in the observations and the model.

To estimate the water exchange of Small Lagoon during summer month, in the GETM-setup particles were released daily. For two-monthly periods, the residence times were calculated then (Figure 9), resulting in a quite consistent spatial pattern. For nearly the whole Small Lagoon the particle age was equal to 60 days, what was the maximal time period, for which the particle were followed. This means, the particles did not left Small Lagoon, so that the water exchange is very limited.

\section{DISCUSSION}

Szczecin Lagoon is strongly utilized by human activities and a crucial supplier of ecosystem services (Inácio et al., 2018; Schernewski et al., 2018). Anthropogenic pressures, especially high nutrient loads, have led to a strongly eutrophied state, while at once central European policies, like the Water Framework Directive (WFD, WFD, 60EC), claim an improved water quality, up to reaching the "Good Ecological State" (GES). Due to its spatial heterogeneity, the inconsistent driving external policies and the opposite reaction to the changed pressures, Szczecin Lagoon can serve as case study for the ongoing re-eutrophication process in many other coastal waters.

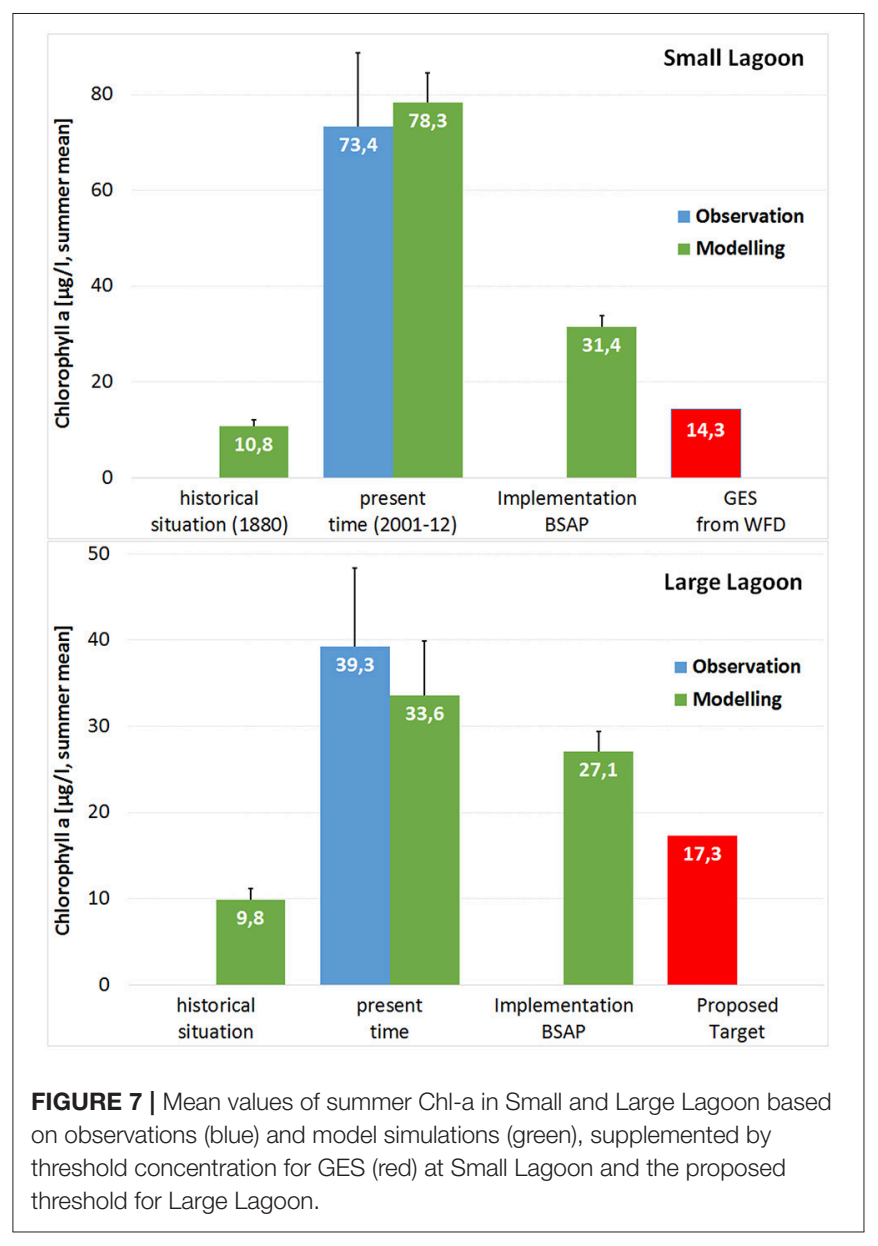

Szczecin Lagoon is characterized by high concentrations of chlorophyll-a (Chl-a) and a low Secchi depth (SD; Figure 1), resulting in a low water transparency. Numerous measures 


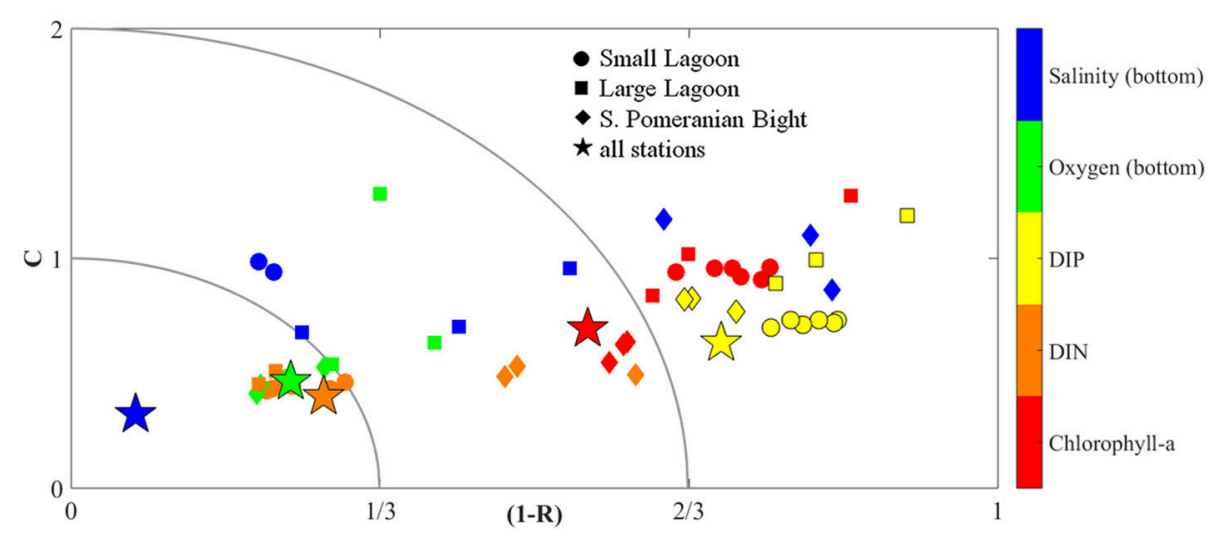

FIGURE 8 | Using the coefficient of correlation (R) and a cost-function (C), grouped into three classes (following Edman and Omstedt, 2013) the performance of the model simulation (ERGOM-MOM) with respect to chlorophyll-a (red), DIN (orange), DIP (yellow), bottom oxygen (green) and salinity (blue) is shown for Small Lagoon (circles), Large Lagoon (squares), Southern Pomeranian Bight (diamonds) and combined for all stations (stars).

were undertaken to reduce the extensive nutrient supply (Kowalkowski et al., 2012; Pastuszak, 2012a,b; Pastuszak and Igras, 2012; Pastuszak and Witek, 2012a), resulting in load reductions of $30 \%(\mathrm{TN})$ and $70 \%$ (TP) compared to the peak values three decades ago (Figure 3). The two parts of Szczecin Lagoon (Small and Large Lagoon; Figure 1) reacted differently to the lowered loads with mostly significant improving trends at Large Lagoon and no trends at all in Small Lagoon (Table 3). Following Duarte et al. (2009) to combine water quality and nutrient load data, revealed that the declining supply of nutrients in the last two decades resulted only in Large Lagoon in a diminishing intensity of phytoplankton blooms (Figure 5) and an increase of SD (Figure 4). The water quality in Small Lagoon remained unaffected (Figure 5). In June 2012, $\mathrm{SD}$ reached even $2.55 \mathrm{~m}$ in the central part of Large Lagoon, which was the highest value since the continuous water quality monitoring started. This is already in the range of historical state (2-2.5 m; Brandt, 1894/96). Starting from 2012, meadows formed by Potamogeton perfoliatus and Myriophyllum spicatum have been regularly observed at the depth of $2-2.2 \mathrm{~m}$ in the eastern part of Large Lagoon (A. Woźniczka, NMFRI, pers. comment). These appearances are practically identical to those reported for the end of the 19th century (Brandt, 1894/96). Together with the re-occurrence of Characeae (Brzeska et al., 2015), this is pointing to an improving ecological state due to the increased water transparency in Large Lagoon. This improvement was accompanied by nearly a halving of Chla concentrations (Figure 4), what is strongly correlated to the reduced TP loads (Figure 5). Hence, further load reductions are the most important measure to improve the water quality enduringly in the eastern part of Szczecin Lagoon.

Contradictory, the western part of Szczecin Lagoon (Small Lagoon) stayed unaffected from the decreased loads. At the end of the 1960s, when the first regular monitoring started, $\mathrm{SD}$ was higher (up to $0.9 \mathrm{~m}$ ) than today (around $0.6 \mathrm{~m}$ ), but already strongly below the historical values and also the GES target (1.7 m; Sagert et al., 2008). The historical range (2-2.5 m; Brandt, 1894/96) was not differentiated between Small and Large
Lagoon, but it seems likely that SD in Small Lagoon was always less than in Large Lagoon due to the hydrographic background conditions. This difference is reflected by our suggested SD targets (1.97 $\mathrm{m}$ for Small Lagoon and $2.87 \mathrm{~m}$ for Large Lagoon). Central problem of Small Lagoon hampering any water quality improvement is thereby the low water exchange and high water residence times (Figure 9). This leads to the long-lasting internal cycling of nutrients, enhanced by the permanent resuspension of organic-rich sediments (Radziejewska and Schernewski, 2008). The low light availability hampers the growth of submerged macrophytes and resulted in a regime shift from a macrophyte dominated system to a phytoplankton dominated one (Duarte et al., 2009). This is further enhanced by the hysteresis effect (Scheffer, 2009), as macrophytes are missing to stabilize the sediments (Karstens et al., 2015) and to reduce the resuspension, resulting in a further lowered water transparency. Berthold et al. (2018) combined nutrient concentrations and phytoplankton biomass in several coastal waters of the southern Baltic Sea and emphasized the importance of hysteresis and resilience factors when reversing eutrophication, concluding that the pure reduction of nutrient loads will not be sufficient to reach the GES thresholds. Duarte (2009) showed for coastal waters, which received high external loads in the 1970ties and 1980ties that returning to oligotrophic conditions is extremely difficult, long time taking, and might in practice be impossible. The recovery of a degraded ecosystem is complex (Duarte et al., 2015), may last decades to centuries (McCrackin et al., 2017) and is often only possible, when external pressures are reversed and additional restoration efforts undertaken (Duarte et al., 2015). Carstensen et al. (2011) concluded from the development between 1970 and 2010 of coastal waters in Europe and USA that the reduction of nutrient loads had no striking impact on surface Chl-a. Riemann et al. (2016) extended the analysis to all coastal waters in Denmark, which experienced since 1990 a bisection of nutrients loads, while SD, eelgrass coverage and benthic gross primary production (Krause-Jensen et al., 2012) increased only slightly. In Small Lagoon, the same occurred, as a lessening of nutrient loads has not led to lower values of eutrophication parameters, so 

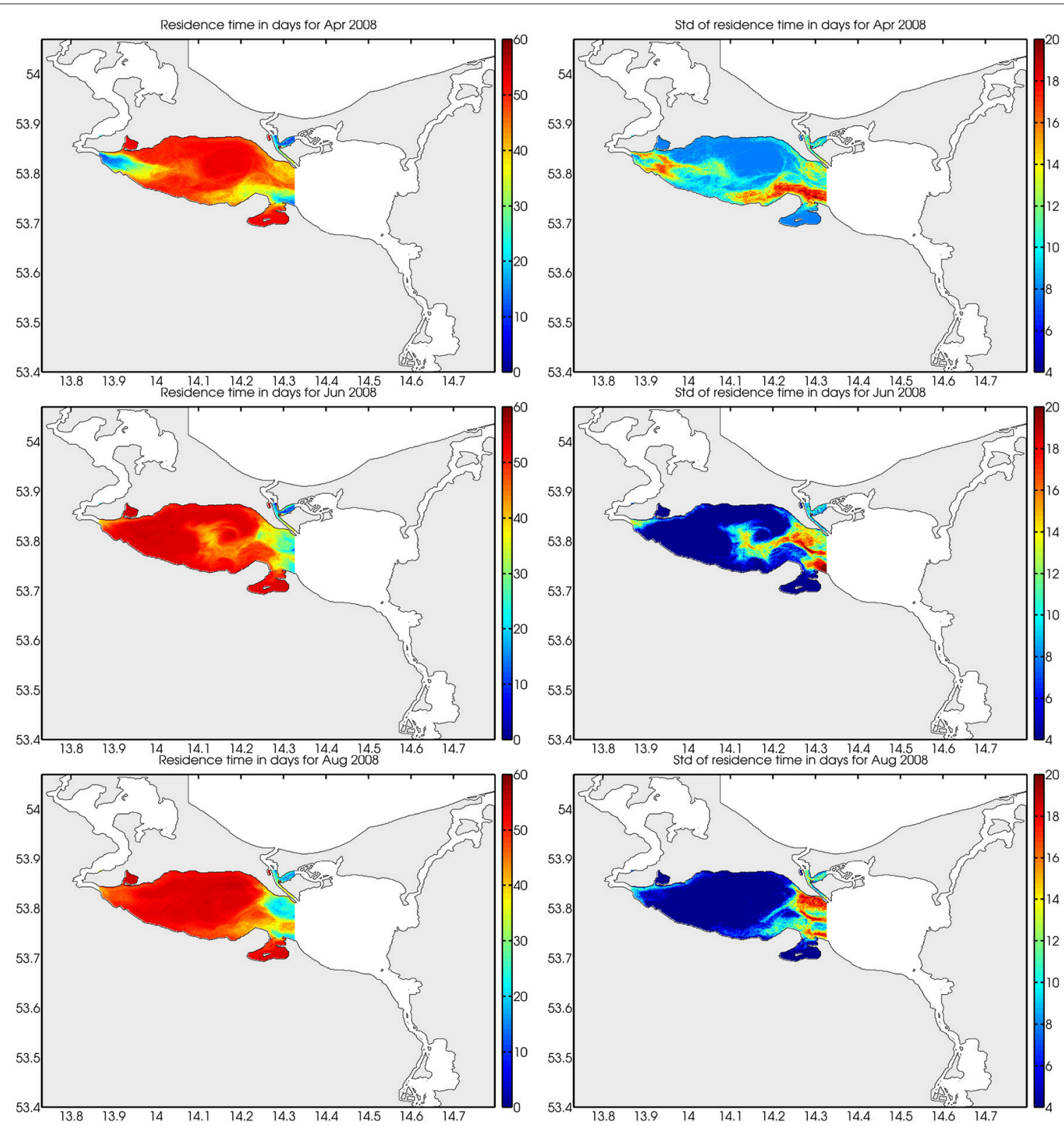

FIGURE 9 | Water residence times in Small Lagoon in April, June and August 2008 (Left) and their standard deviations (Right) calculated using ERGOM-GETM. Small Lagoon is always characterized by residence times near to the maximal value (the particle were only followed for 60 days).

that reaching the desired GES is not possible only by reducing the nutrient loads. Further, Petkuviene et al. (2016) and Zilius et al. (2014) reported for muddy sediments in Curonian Lagoon (which are also dominating in Small Lagoon) a release of reactive $\mathrm{P}$, boosting phytoplankton blooms. Boström and Pettersson (1982) and Jensen and Andersen (1992) observed a release of $\mathrm{P}$ in shallow lakes also under oxic conditions, concluding that not only the pure redox conditions at the sediment-water interface are crucial for the P-release. Søndergaard et al. (1996) showed the strong influence of resuspension on pelagic nutrient concentrations in shallow lakes and explained this by a high ratio of sediment surface to water column. This holds also for Small Lagoon, where average water depth is below $4 \mathrm{~m}$. To improve water quality in Small Lagoon in a suitable manner, it is therefore not only important to further reduce the external nutrient supply, but to tackle the resuspension and the hysteresis effect. Submerged vegetation is missing to stabilize the sediments, to reduce the resuspension of particles and to bind excess nutrients (especially P).

Hence, an extension of measures (in addition to limiting the nutrient loads) within Small Lagoon seems necessary or authorities have to acknowledge that GES cannot be reached. Possible internal measures cannot replace nutrient input reductions, but they are adequate supplements if they affect the central problems, which are the missing submerged vegetation and the frequent resuspension of sediments. Berthold 
et al. (2018) discussed therefore bio-manipulation approaches, like the planting of submerged macrophytes or the transition of the food web from planktivorous to piscivorous fish. More promising is to increase the biomass of filter feeders by supplying them appropriate material to grow on (Stybel et al., 2009) as suitable hard substrate is missing in Small Lagoon. Filter feeders reduce the phytoplankton density and improve thereby the underwater light climate. Petersen et al. (2008) showed that in an eutrophied coastal water in Denmark (Ringkobing Fjord) a sudden regime shift towards a clear water state could be initialized by supporting the growth of already occurring suspension feeders. This led to an increasing coverage of benthic vegetation and an ongoing improving trend of water transparency, even when the suspension feeder biomass did not further increase. To ensure at once the active removal of nutrients, mussel farm approaches can be adapted, allowing to harvest the mussels, when they are big enough (Schernewski et al., 2018). Schernewski et al. (2012b) estimated that in Small Lagoon every year $1,000 \mathrm{t} \mathrm{N}$ and $70 \mathrm{t} \mathrm{P}$ could be taken out by mussel farms utilizing Dreissena polymorpha. SD could be increased by up to $30 \mathrm{~cm}$, so that light availability and overall growing conditions of submerged macrophytes would improve. The efficiency of mussel farms to locally improve SD and water quality was carried out along Baltic coastal waters in Sweden (Lindahl et al., 2005), Denmark (Nielsen et al., 2016) or Germany (Schröder et al., 2014). With a spatial explicit mussel farm simulation model, Friedland et al. (2018) showed that SD could locally be increased even up to $60 \mathrm{~cm}$, but at an increasing risk of anoxia, resulting in a further P-liberation from the sediment. Nevertheless, even in the maximal scenario of Friedland et al. (2018), the potential water quality improvement was not enough to reach the GES thresholds of Chl-a. Instead of a maximal mussel farm approach with unpredictable implications, most promising is to establish spatially and temporally restricted farms to support the (re-)occurrence of submerged macrophytes at wisely chosen spots (Schernewski et al., 2018)-presuming that they will grow, if the underwater light conditions get good enough due to the clearance effect of the mussels. After the initial recovery of the submerged vegetation, the mussel farm could be dismantled and moved to a new spot to prevent a disturbance of the newly grown vegetation.

Yet, water quality management measures focused exclusively on reducing nutrient loads, which are the most important anthropogenic driver resulting in the present eutrophied state. But the management is hampered by non-harmonized nutrient load targets from the driving legislations (Table 2). The allowable nutrient inputs from the two central eutrophication related European policies WFD and MSFD (Marine Strategy Framework Directive; MSFD, 2008/56/EC) are not synchronized, reflected by not harmonized load thresholds (Table 2). Central program to reach the MSFD targets in the Baltic Sea is the HELCOM Baltic Sea Action Plan (BSAP; HELCOM, 2013b), which includes binding nutrient input thresholds (Maximal Allowable Inputs, MAI) for all Baltic states. Although aiming on the right issuesmainly to fight the eutrophication in the Baltic Sea-HELCOM BSAP (HELCOM, 2013b) is not suitable for a coastal water like Szczecin Lagoon (Håkanson and Bryhn, 2008; Håkanson et al., 2010). Szczecin Lagoon is not an explicit part of the ecosystem model NEST (Savchuk et al., 2012), which was used to determine the MAI. Instead, it is combined with the entire Pomeranian Bight and parts of the Bornholm Basin to one subbasin. This means that the nutrient retention within Szczecin Lagoon is not included in NEST, although at least 20\% of Oder's nutrient loads are retained in Szczecin Lagoon according to our simulations. (Pastuszak et al., 2005) reported retention rates even up to $45 \%$ for $\mathrm{N}$ and $37 \%$ for $\mathrm{P}$ loads. The reduction demands by the updated version of BSAP (HELCOM, 2013b) resulted in unreachable low target, which is nearly the same as in the preindustrial situation (Table 2) and $16.3 \%$ more ambitious than the German WFD target (0.1 mg TP/l; Table 2; BLANO, 2014). Håkanson and Bryhn (2008) and Håkanson et al. (2010) grouped eutrophication indicators according to the trophic state of the different parts of the Baltic Sea and concluded that only Gulf of Finland, Gulf of Riga, Kaliningrad proximity, Vistula, and Szczecin Lagoon are eutrophic and need attention. Therefore, all actions related to nutrient load reduction should be focused on these regions but not on the entire Baltic Sea. Håkanson et al. (2010) emphasized further that the proposed level of load reductions may need updating due to further reorganization of the Baltic ecosystem as a result of regime shifts (Möllmann et al., 2005, 2009; Tomczak et al., 2016; Zettler et al., 2017) and due to the impact of climate change on water quality (Friedland et al., 2012; Meier et al., 2012a,b, 2014). For the central Baltic Sea, not the nutrient load to Szczecin Lagoon is crucial, but the nutrient export from it to the open Baltic. Hence, strengthening the nutrient removal within Szczecin Lagoon, e.g., by establishing mussel farms also in the eastern part, could therefore be a support to reach the targets of the BSAP.

If mussel farms are proven to be a suitable supporting measure to enable a sustainable water quality improvement, transferring them to other coastal systems seems possible. Applying the lagoon categorization of Kjerfve (1986), Kjerfve and Magill (1989), and Umgiesser et al. (2014) to Szczecin Lagoon as whole water body is not possible due to its high spatial heterogeneity. While Large Lagoon is a restricted lagoon, Small Lagoon is choked, comparable to lagoons like Mar Menor (Mediterranean Sea), where low freshwater runoff and a limited exchange with the open sea take place (Umgiesser et al., 2014). But, Mar Menor reacted opposite to the increased nutrient loads over the past decades with high water transparency (up to $5 \mathrm{~m}$ Secchi Depth; Pérez-Ruzafa et al., 2008, 2018) and only a low phytoplankton density, resulting in a classification as oligotrophic water (Marín et al., 2015). On the other hand, for Curonian Lagoon (Baltic Sea) a decline of submerged macrophytes due to eutrophication is also reported (Sinkevičienè et al., 2017). The zonation of Curonian is thereby quite comparable to Szczecin Lagoon with a slow water renewal in the southern part (Umgiesser et al., 2016), while the northern part is flushed out as fast as Large Lagoon (76.5 days; Umgiesser et al., 2016). For Curonian Lagoon the potential of mussel farms is already discussed (Bagdanavičiūte et al., 2018). Other coastal waters like Darss-Zingst-BoddenChain (Schubert et al., 2010) or Rügensche Binnenbodden (both German Baltic Sea; Selig et al., 2007) experienced a comparable strong reduction of submerged vegetation and water transparency, and are not reacting to decreased nutrients loads (Berthold et al., 2018). 
Many other trans-boundary waters (Newton et al., 2014), e.g., Vistula Lagoon (Chubarenko et al., 2014), Curonian Lagoon (Povilanskas et al., 2014) or Flensborg Fjord, are lacking like Szczecin Lagoon from a consistent and joint water quality target setting across political borders. Applying the Integrated Modeling approach of Schernewski et al. (2015) to both parts of Szczecin Lagoon allowed to derive harmonized target values (Figure 7), accounting the differences in the present state of both parts, but also the differing reactions to nutrient load changes. It can therefore be a blueprint for other transboundary waters. The method of Schernewski et al. (2015) to define GES targets was an important step forward, as it allowed to derive consistent and harmonized targets for all German coastal waters of the Baltic Sea. Although it included the water body specific present states as well as simulated reactions to changed nutrient loads, the estimated pre-industrial state (referring to 1880) might be unrealistic low for some waters after a century of excess nutrient loads, e.g., the simulated Chl-a concentration in Small Lagoon for 1880 is approximately $14 \%$ of the recent one. Beside the uncertainty of the model simulations, this deviation raises the question if 1880 is suitable as state referring to a very good water quality or if water quality targets in Szczecin Lagoon should base on another reference state, e.g., before 1960. On the other hand, the pre-industrial nutrient loads can only be derived from models. Although using both times the catchment model MONERIS, estimated pre-industrial TN loads by Gadegast and Venohr (2015) were double of Gadegast et al. (2012) (Table 2). Following the model results for a very optimistic future scenario (Figures 5, 6), where all nutrient load reductions were in charge, GES was still not achieved. The mismatch between water quality targets and nutrient load thresholds stresses out the importance of complementing water quality targets of coastal waters with reduction demands in the catchment area, as introduced by Arheimer et al. (2015) or within the updated Danish Water Action Plan (Maar et al., 2016). Although differing in details, these approaches have in common that they are tailor-made and include the specific characteristics of the water bodies and catchment areas.

The used ecosystem model (ERGOM-MOM) was well able to reproduce the mean eutrophication parameters (Figure 7), although the model skill (Figure 8) revealed some weaknesses. Future improvements may result in more reliable estimates of the pre-industrial state and derived GES thresholds. ERGOM was in its initial phase (Neumann, 2000; Neumann et al., 2002) adjusted to the open Baltic Sea, dominated by phytoplankton communities not being exposed to a steady supply of nutrients, like in Szczecin Lagoon. Further, the interaction with higher trophic levels and macrophytes is missing. 45 trophic-functional components are identified of Large Lagoon's food web (Wolnomiejski and Witek, 2013), while ERGOM only includes three phytoplankton groups and one bulk zooplankton, in which not only all zooplankton species but also all their individual life stages are merged. Nevertheless, with respect to the nutrient dynamics, ERGOM is mostly well adjusted. With denitrification, the most important $\mathrm{N}$ retention process is included, which contributes up to $70 \%$ of the $\mathrm{N}$ retention within Szczecin Lagoon (Pastuszak et al., 2005). In our simulations, denitrification results in an average loss of $4.7 \mathrm{mmol} \mathrm{N} / \mathrm{m}^{2} / \mathrm{d}$ or $16,500 \mathrm{t} \mathrm{N}$ per year (integrated over the whole lagoon; Allin et al., 2017). This fits with reported values, e.g., 2-4 mmol N/m²/d (Radziejewska and Schernewski, 2008 ) or 15,800 t N/a (based on model data; Wielgat and Witek, 2004), while (Dahlke et al., 1998) reported an annual loss of only approximately $500 \mathrm{t} \mathrm{N}$ for Small Lagoon (based on observations). On the other hand, the liberation of $\mathrm{P}$ under anoxic conditions is involved, but might not be enough, if $\mathrm{P}$ is released from the sediments, although in the bottom waters oxygen is still available. Here the description of the early diagenesis with one static layer that can be either oxic or anoxic is not sufficient, but the qualitative and quantitative description will be improved in the future (Radtke et al., 2018).

\section{CONCLUSION}

- Due to excess of nutrient loads over the past century, Szczecin Lagoon is strongly eutrophied and not in the desired "Good Ecological State," as claimed by Water Framework Directive (WFD).

- $\mathrm{TN}$ (TP) loads are nowadays 30\% (70\%) lower than at the peak around 1990, but the decreasing trend is only significant for TN and TP in Oder. Further reductions are necessary to fulfill load targets from the German WFD implementation strategy and the HELCOM Baltic Sea Action Plan. Both target sets need a harmonization.

- In the Polish eastern part of Szczecin Lagoon, the reduced loads led to a substantial improvement of water quality in the last decades. Ongoing load reductions are needed to further improve the water quality there.

- Water quality in the German western part remained unaffected from the reduced loads due to the long water residence times, the frequent resuspension of sediment and the decline of submerged vegetation. A re-eutrophication of Small Lagoon and reaching the GES purely by reducing the nutrient loads is not possible.

- To improve the water quality in Small Lagoon, internal measures are necessary, which directly elevate water transparency to improve the growing conditions of submerged macrophytes. Most promising approach are mussel farms.

- Consistent and harmonized water quality thresholds are derived for both parts. By implementing them, Szczecin Lagoon could get a blueprint for other transboundary waters.

\section{AUTHOR CONTRIBUTIONS}

RF was responsible for overall structure of the manuscript, compiling the data, running the simulations and for writing the manuscript. MP collected nutrient loads of Oder and contributed to the writing. GS contributed to the writing. UG and DP were responsible for the simulation of the water exchange. IG conducted the flow-normalization of loads. 


\section{FUNDING}

The work was supported by BONUS BALTCOAST (03F0717A) and partly by KÜNO project MOSSCO-Synthese (03F0740B). BONUS BALTCOAST project has received funding from BONUS (Art. 185), funded jointly by the EU and Baltic Sea national funding institutions.

\section{REFERENCES}

Ackermann, A., Mahnkopf, J., Heidecke, C., and Venohr, M. (2016). Reducing agricultural nitrogen inputs in the German Baltic Sea catchment - trends and policy options. Water Sci. Technol. 74, 1060-1068. doi: 10.2166/wst.2016.267

Allin, A., Schernewski, G., Friedland, R., Neumann, T., and Radtke, H. (2017). Climate change effects on denitrification and associated avoidance costs in three Baltic river basin - coastal sea systems . J. Coast. Conserv. 21, 561-569. doi: 10.1007/s11852-017-0530-8

Arheimer, B., Nilsson, J., and Lindström, G. (2015). Experimenting with coupled hydro-ecological models to explore measure plans and water quality Goals in a semi-enclosed Swedish Bay. Water 7:3906. doi: 10.3390/w7073906

BACC (2015). Second Assessment of Climate Change for the Baltic Sea Basin. Berlin; Heidelberg: Springer-Verlag.

Bachor, A. (2005). Nährstoff- und Schwermetallbilanzen der Küstengewässer Mecklenburg-Vorpommerns unter besonderer Berücksichtigung ihrer Sedimente (in German), volume 2. Schriftenreihe des Landesamtes für Umwelt Naturschutz und Geologie Mecklenburg-Vorpommern (Greifswald).

Bagdanavičiūtė, I., Umgiesser, G., Vaičiūtè, D., Bresciani, M., Kozlov, I., and Zaiko, A. (2018). Gis-based multi-criteria site selection for zebra mussel cultivation: addressing end-of-pipe remediation of a eutrophic coastal lagoon ecosystem. Sci. Total Environ. 634, 990-1003. doi: 10.1016/j.scitotenv.2018.03.361

Bangel, H., Schernewski, G., Bachor, A., and Landsberg-Uczciwek, M. (2004). "Spatial pattern and long-term development of water quality in the Oder Estuary," in The Oder Estuary-against the background of the European Water Framework Directive, Vol. 57, eds G. Schernewski, and T. Dolch (Warnemünde: Marine Science Reports), 17-65.

Baudler. H., Birr, H. D., Dahlke, S., Hupfer, P., Kozerski, H. P., Lampe, R., et al. (2012). Die Erforschung der nordostdeutschen Boddengewässer der Ostsee. Historisch-meereskundliches Jahrbuch 18, 73-134.

Behrendt, H., and Dannowski, R. E. (2005). Nutrients and Heavy Metals in the Odra River System. Berlin: Weißensee Verlag .

Behrendt, H., Opitz, D., Kolanek, A., Korol, R., and Strońska, M. (2008). Changes of the nutrient loads of the Odra River during the last centurytheir causes and consequences. J. Water Land Develop. 12, 127-144. doi: 10.2478/v10025-009-0010-0

Berthold, M., Karsten, U., von Weber, M., Bachor, A., and Schumann, R. (2018). Phytoplankton can bypass nutrient reductions in eutrophic coastal water bodies. Ambio 47, 146-158. doi: 10.1007/s13280-017-0980-0

BLANO (2014). Harmonisierte Hintergrund- und Orientierungswerte für Nährstoffe und Chlorophyll-a in den deutschen Küstengewässern der Ostsee sowie Zielfrachten und Zielkonzentrationen für die Einträge über die Gewässer (in German). Hrsg.: Bundesministerium für Umwelt, Naturschutz und Reaktorsicherheit. Available online at: https://www.meeresschutz.info/ sonstige-berichte.html

Borja, A., Dauer, D. M., and Grémare, A. (2012). The importance of setting targets and reference conditions in assessing marine ecosystem quality. Ecol. Indic. 12, 1-7. doi: 10.1016/j.ecolind.2011.06.018

Boström, B., and Pettersson, K. (1982). Different patterns of phosphorus release from lake sediments in laboratory experiments. Hydrobiologia 91, 415-429. doi: 10.1007/PL00020032

Brandt, K. (1894/96). Über das Stettiner Haff (in German). Wissenschaftliche Meeresuntersuchungen, Band 1 (Heft 2), Kiel und Leipzig, 147p.

Brockmann, U., Topcu, D., and Schütt, M. (2005). Referenz- und Schwellenwerte für die Küsten- und Übergangsgewässer an der deutschen Nord-und Ostseeküste. Bericht, BLM-AG, 19.

\section{ACKNOWLEDGMENTS}

We thank A. Hiller (IOW) for supporting the map compiling (Figure 2) and P. Stålnacke (nibio) for supporting the flownormalization. Supercomputing power was provided by HLRN (North-German Supercomputing Alliance). We thank LUNG and WIOS Szczecin for providing the observational data.

Brzeska, P., Wozniczka, A., Pelechaty, M., and Blindow, I. (2015). New records of Chara connivens P. Salzmann ex A. Braun 1835-an extremely rare and protected species in Polish brackish waters. Acta Soc. Botan. Poloniae 84, 143-146. doi: 10.5586/asbp.2015.010

Burchard, H., and Bolding, K. (2002). GETM - A general estuarine transport model. Scientific Documentation, Technical Report EUR 20253 EN.

Carstensen, J., Sanchez-Camacho, M., Duarte, C. M., Krause-Jensen, D., and Marba, N. (2011). Connecting the Dots: responses of Coastal ecosystems to changing nutrient concentrations. Environ. Sci. Technol. 45, 9122-9132. doi: 10.1021/es202351y

Chubarenko, B., Domnin, D., Navrotskaya, S., Stont, Z., Chechko, V., Bobykina. V., et al. (2014). "Transboundary lagoons of the Baltic Sea," in The Diversity of Russian Estuaries and Lagoons Exposed to Human Influence, eds Kosyan and Ruben (Cham: Springer International Publishing), 149-189.

CIS-COAST (2003). Transitional and Coastal Waters Typology, Reference Conditions and Classification Systems, Common Implementation Strategy for the Water Framework Directive (2000/60/EC). Guidance document No 5, European Communities.

Dahlke, S., Wolf, C., and Bange, H. (1998). "Mikrobieller N-, S- und C- Umsatz und die Emission von N2O, und CH4 im Greifswalder Bodden und im westlichen Teil des Oderästuars (in German)," in Greifswalder Bodden und Oder-ÄstuarAustauschprozesse (GOAP), Synthesebericht des Verbundprojektes, ed R. Lampe (Greifswald: Geogr Arb 16), 30.

Duarte, C. M. (2009). Coastal eutrophication research: a new awareness. Hydrobiologia 629, 263-269. doi: 10.1007/s10750-009-9795-8

Duarte, C. M., Borja, A., Carstensen, J., Elliott, M., Krause-Jensen, D., and Marbà, N. (2015). Paradigms in the recovery of estuarine and Coastal ecosystems. Estuar. Coasts 38, 1202-1212. doi: 10.1007/s12237-013-9750-9

Duarte, C. M., Conley, D. J., Carstensen, J., and Sánchez-Camacho, M. (2009). Return to Neverland: shifting baselines affect eutrophication restoration targets. Estuar. Coasts 32, 29-36. doi: 10.1007/s12237-008-9111-2

Edman, M., and Omstedt, A. (2013). Modeling the dissolved CO_2 system in the redox environment of the Baltic Sea. Limnol. Oceanogr. 58, 74-92. doi: 10.4319/lo.2013.58.1.0074

Eilola, K., Gustafsson, B., Kuznetsov, I., Meier, H., Neumann, T., and Savchuk, O. (2011). Evaluation of biogeochemical cycles in an ensemble of three stateof-the-art numerical models of the Baltic Sea. J. Marine Syst. 88, 267-284. doi: 10.1016/j.jmarsys.2011.05.004

Friedland, R., Buer, A.-L., Dahlke, S., and Schernewski, G. (2018). Spatial effects of different zebra mussel (Dreissena spp.) farming strategies in an eutrophic Baltic lagoon. Front. Environ. Sci. Marine Pollut. Available online at: https:// www.frontiersin.org/articles/10.3389/fenvs.2018.00158

Friedland, R., Neumann, T., and Schernewski, G. (2012). Climate change and the Baltic Sea action plan: model simulations on the future of the western Baltic Sea. J. Marine Syst. 105, 175-186. doi: 10.1016/j.jmarsys.2012. 08.002

Gadegast, M., Hirt, U., Opitz, D., and Venohr, M. (2012). Modelling changes in nitrogen emissions into the Oder River System 1875-1944. Reg. Environ. Change 12, 571-580. doi: 10.1007/s10113-011-0270-5

Gadegast, M., Hirt, U., and Venohr, M. (2014). Changes in waste water disposal for Central European River catchments and its nutrient impacts on surface waters for the period 1878-1939. Water Air Soil Pollut. 225, 1-17. doi: $10.1007 /$ s11270-014-1914-0

Gadegast, M., and Venohr, M. (2015). Modellierung historischer Nährstoffeinträge und -frachten zur Ableitung von Nährstoffreferenz- und Orientierungswerten für mitteleuropäische Flussgebiete (in German). Bericht erstellt im Auftrag des 
NLWKN. 39 Seiten, Available online at: http://www.nlwkn.niedersachsen.de/ download/98787

Garcia, N. V., Wasilewicz, M., Tronscoso, R. A., Zalewski, T., Soszka, H., Kolada, A., et al. (2012). Weryfikacja wartości granicznych dla oceny stanu ekologicznego rzek $i$ jezior $w$ zakresie elementów fizykochemicznych $z$ uwzglednieniem warunków charakterystycznych dla poszczególnych typów wód. ADASA, IOŚPIB, 180.

Gräwe U, Holtermann P, K. K. B. H. (2015). Advantages of vertically adaptive coordinates in numerical models of stratified shelf seas. Ocean Model. 92, 56-68. doi: 10.1016/j.ocemod.2015.05.008

Gräwe, U., Deleersnijder, E., Shah, S. H. A. M., and Heemink, A. W. (2012). Why the Euler scheme in particle tracking is not enough: the shallow-sea pycnocline test case. Ocean Dyn. 62, 501-514. doi: 10.1007/s10236-012-0523-y

Grimvall, A., Stålnacke, P., and Tonderski, A. (2000). Time scales of nutrient losses from land to sea - a European perspective. Ecol. Eng. 14, 363-371. doi: 10.1016/S0925-8574(99)00061-0

Gustafsson, B. G., Schenk, F., Blenckner, T., Eilola, K., Meier, H. E. M., Müller-Karulis, B., et al. (2012). Reconstructing the development of Baltic Sea Eutrophication 1850-2006. AMBIO 41, 534-548. doi: 10.1007/s13280-012-0318-x

Håkanson, L., and Bryhn, A. C. (2008). Eutrophication in the Baltic SeaPresent Situation, Nutrient Transport Processes, Remedial Strategies. Springer; Environmental Science and Engineering.

Håkanson, L., Stabo, H. R., and Bryhn, A. C. (2010). The Fish Production Potential of the Baltic Sea. A new General Approach for Optimizing Fish Quota Including a Holistic Management Plan Based on Ecosystem Modeling. Heidelberg; Dordrecht; London; New York, NY: Springer.

Heemink, A. W. (1990). Stochastic modelling of dispersion in shallow water. Stoch. Hydrol. Hydraul. 4, 161-174.

HELCOM (2007). Baltic Sea Action Plan. HELCOM Ministerial Meeting Krakow. Available online at: http://www.helcom.fi/Documents/Baltic\%20sea\%20action $\% 20$ plan/BSAP_Final.pdf

HELCOM (2013a). Approaches and Methods for Eutrophication Target Setting in the Baltic Sea Region. HELCOM Baltic Sea Environment Proceedings 133.

HELCOM (2013b). HELCOM Copenhagen Ministerial Declaration: Taking Further Action to Implement the Baltic Sea Action Plan-Reaching a Good Environmental Status for a Healthy Baltic Sea. . HELCOM Declaration: Copenhagen.

HELCOM (2013c). Summary Report on the Development of Revised Maximum Allowable Inputs (MAI) and Updated Country Allocated Reduction Targets (CART) of the Baltic Sea Action Plan. Available online at: http://www.helcom.fi/ Documents/Ministerial2013/Associated\%20documents/Supporting/Summary \%20report\%20on\%20MAI-CART.pdf

Hirsch, R. M., and Slack, J. R. (1984). A nonparametric trend test for seasonal data with serial dependence. Water Resour. Res. 20, 727-732.

Hirt, U., Mahnkopf, J., Gadegast, M., Czudowski, L., Mischke, U., Heidecke, C., et al. (2014). Reference conditions for rivers of the German Baltic Sea catchment: reconstructing nutrient regimes using the model MONERIS. Reg. Environ. Change 14, 1123-1138. doi: 10.1007/s10113-0130559-7

Hofmeister, R., Burchard, H., and Beckers, J.-M. (2010). Non-uniform adaptive vertical grids for 3d numerical ocean models. Ocean Model. 33, 70-86. doi: 10.1016/j.ocemod.2009.12.003

Hussian, M., Grimvall, A., and Petersen, W. (2004). Estimation of the human impact on nutrient loads carried by the Elbe river. Environ. Monit. Assess. 96, 15-33. doi: 10.1023/B:EMAS.0000031722.88972.62

Inácio, M., Schernewski, G., Nazemtseva, Y., Baltranaitė, E., Friedland, R., and Benz, J. (2018). Ecosystem services provision today and in the past: a comparative study in two Baltic lagoons. Ecol. Res. 33, 1255-1274. doi: $10.1007 / \mathrm{s} 11284-018-1643-8$

Jadczyszyn, T., and Rutkowska, A. (2012). "The role of regulations in the protection of water resources," in Temporal and Spatial Differences in Emission of Nitrogen and Phosphorus From Polish Territory to the Baltic Sea, eds M. Pastuszak and J. Igras (Gdynia-Puławy: National Marine Fisheries Research Institute-Institute of Soil Science and Plant Cultivation - State Research Institute-Fertilizer Research Institute), 245-261.

Jensen, H. S., and Andersen, F. O. (1992). Importance of temperature, nitrate, and ph for phosphate release from aerobic sediments of four shallow, eutrophic lakes. Limnol. Oceanogr. 37, 577-589.
Karstens, S., Buczko, U., and Glatzel, S. (2015). Phosphorus storage and mobilization in coastal Phragmites wetlands: influence of local-scale hydrodynamics . Estuar. Coast. Shelf Sci. 164, 124-133. doi: 10.1016/j.ecss.2015.07.014

Kjerfve, B. (1986). “Comparative oceanography of coastal lagoons," in Estuarine Variability, ed D. A. Wolfe (Academic Press), 63-81.

Kjerfve, B., and Magill, K. (1989). Geographic and hydrodynamic characteristics of shallow coastal lagoons. Mar. Geol. 88, 187-199.

Klingbeil, K., and Burchard, H. (2013). Implementation of a direct nonhydrostatic pressure gradient discretisation into a layered ocean model. Ocean Model., 65, 64-77. doi: 10.1016/j.ocemod.2013.02.002

Kowalkowski, T., and Buszewski, B. (2006). Emission of nitrogen and phosphorus in Polish rivers: past, present, and future trends in the vistula river catchment. Environ. Eng. Sci. 23, 615-622. doi: 10.1089/ees.2006.23.615

Kowalkowski, T., Pastuszak, M., Igras, J., and Buszewski, B. (2012). Differences in emission of nitrogen and phosphorus into the Vistula and Oder basins in 19952008 - Natural and anthropogenic causes (MONERIS model). J. Mar. Syst. 89, 48-60. doi: 10.1016/j.jmarsys.2011.07.011

Krause-Jensen, D., Markager, S., and Dalsgaard, T. (2012). Benthic and pelagic primary production in different nutrient regimes. Estuar. Coasts 35, 527-545. doi: 10.1007/s12237-011-9443-1

Libiseller, C., and Grimvall, A. (2002). Performance of partial Mann-Kendall tests for trend detection in the presence of covariates. Environmetrics 13, 71-84. doi: 10.1002/env.507

Lindahl, O., Hart, R., Hernroth, B., Kollberg, S., Loo, L.-O., Olrog, L., et al. (2005). Improving marine water quality by mussel farming: a profitable solution for Swedish society. Ambio 34, 131-138. doi: 10.1579/0044-7447-34.2.131

Maar, M., Markager, S., Skovgaard Madsen, K., Windolf, J., Lyngsgaard, M. M., Andersen, H.E., et al. (2016). The importance of local versus external nutrient loads for Chl a and primary production in the Western Baltic Sea. Ecol. Model. 320, 258-272. doi: 10.1016/j.ecolmodel.2015.09.023

Marín, A., Lloret, J., Velasco, J., and Bello, C. (2015). "The physio-geographical background and ecology of Mar Menor," in Coastal Lagoons Europe, Vol. 39. (London: IWA Publishing), 39-48.

McCrackin, M. L., Jones, H. P., Jones, P. C., Moreno-Mateos, D. (2017). Recovery of lakes and coastal marine ecosystems from eutrophication: a global metaanalysis. Limnol. Oceanogr. 62, 507-518. doi: 10.1002/lno.10441

Meier, H. E. M., Andersson, H. C., Arheimer, B., Donnelly, C., Eilola, K., Gustafsson, B. G., et al. (2014). Ensemble modeling of the Baltic sea ecosystem to provide scenarios for management. AMBIO 43, 37-48. doi: 10.1007/s13280-013-0475-6

Meier, H. E. M., Edman, M., Eilola, K., Placke, M., Neumann, T., Andersson. H. C., et al. (2018). Assessment of eutrophication abatement scenarios for the Baltic sea by multi-model ensemble simulations. Front. Mari. Sci. 5:440. doi: 10.3389/fmars.2018.00440

Meier, H. E. M., Hordoir, R., Andersson, H. C., Dieterich, C., Eilola, K., Gustafsson, B. G., et al. (2012a). Modeling the combined impact of changing climate and changing nutrient loads on the Baltic Sea environment in an ensemble of transient simulations for 1961-2099. Climate Dyn. 39, 2421-2441. doi: 10.1007/s00382-012-1339-7

Meier, H. E. M., Müller-Karulis, B., Andersson, H. C., Dieterich, C., Eilola, K., Gustafsson, B. G., et al. (2012b). Impact of climate change on ecological quality indicators and biogeochemical fluxes in the Baltic sea: a multi-model ensemble study. Ambio 41, 558-573. doi: 10.1007/s13280-012-0320-3

Michalak, A. (2016). Study role of climate change in extreme threats to water quality. Nature 535:349. doi: 10.1038/535349a

Möllmann, C., Diekmann, R., Müller-Karulis, B., KKornilovs, G., Plikshs, M., and Axe, P. (2009). Reorganization of a large marine ecosystem due to atmospheric and anthropogenic pressure: a discontinuous regime shift in the Central Baltic Sea. Global Change Biol. 15, 1377-1393. doi: 10.1111/j.1365-2486.2008.01814.x

Möllmann, C., Kornilovs, G., Fetter, M., and Köster, F. W. (2005). Climate, zooplankton, and pelagic fish growth in the central Baltic Sea. ICES J. Marine Sci. 62, 1270-1280. doi: 10.1016/j.icesjms.2005.04.021

MSFD (2008/56/EC). Commission of the European Communities Directive 2008/56/EC of the European Parliament and of the Council of 17 June 2008 Establishing a Framework for Community Action in the Field of Marine Environmental Policy (Marine Strategy Framework Directive). Official Journal of the European Union L 164. 
Nausch, G., Bachor, A., Petenati, T., Voss, J., and von Weber, M. (2011). Nährstoffe in den deutschen Küstengewässern der Ostsee und angrenzenden Gebieten (in German). Meeresumwelt Aktuell Nord- und Ostsee 1, 1-16.

Neumann, T. (2000). Towards a 3D-ecosystem model of the Baltic Sea. J. Mar. Syst. 25, 405-419. doi: 10.1016/S0924-7963(00)00030-0

Neumann, T., Fennel, W., and Kremp, C. (2002). Experimental simulations with an ecosystem model of the Baltic Sea: a nutrient load reduction experiment. Global Biogeochem. Cycles 16, 7-1-7-19. doi: 10.1029/2001GB001450

Neumann, T., and Schernewski, G. (2008). Eutrophication in the Baltic Sea and shifts in nitrogen fixation analyzed with a 3D ecosystem model. J. Mar. Systems, 74, 592-602. doi: 10.1016/j.jmarsys.2008.05.003

Newton, A., Icely, J., Cristina, S., Brito, A., Cardoso, A. C., Colijn, F., et al. (2014). An overview of ecological status, vulnerability and future perspectives of European large shallow, semi-enclosed coastal systems, lagoons and transitional waters. Estuar. Coast. Shelf Sci. 140, 95-122. doi: 10.1016/j.ecss.2013.05.023

Nielsen, P., Cranford, P. J., Maar, M., and Petersen, J. K. (2016). Magnitude, spatial scale and optimization of ecosystem services from a nutrient extraction mussel farm in the eutrophic Skive Fjord, Denmark. Aquac. Environ. Interact. 8, 311-329. doi: 10.3354/aei00175

Oenema, O., van Liere, L., and Schoumans, O. (2005). Effects of lowering nitrogen and phosphorus surpluses in agriculture on the quality of groundwater and surface water in the Netherlands. J. Hydrol. 304, 289-301. doi: 10.1016/j.jhydrol.2004.07.044

Oliveira, A., and Baptista, A. M. (1997). Diagnostic modeling of residence times in estuaries. Water Resour. Res. 33, 1935-1946.

Omstedt, A., Edman, M., Claremar, B., Frodin, P., Gustafsson, E., Humborg, C., et al. (2012). Future changes in the Baltic Sea acid-base $(\mathrm{pH})$ and oxygen balances. Tellus B 64:19586. doi: 10.3402/tellusb.v64i0.19586

Pacanowski, R. C., and Griffies, S. M. (2000). MOM 3.0 Manual. Princeton, NJ: NOAA/Geophysical Fluid Dynamics Laboratory.

Pachauri, R. K., Allen, M. R., Barros, V. R., Broome, J., Cramer, W., Christ, R., et al. (2014). Climate Change 2014: Synthesis Report. Contribution of Working Groups I, II and III to the Fifth Assessment Report of the Intergovernmental Panel on Climate Change. Geneva: IPCC.

Pastuszak, M. (2012a). "Description of the Baltic Sea catchment area - focus on the Polish sub-catchment," in Temporal and Spatial Differences in Emission of Nitrogen and Phosphorus From Polish Territory to the Baltic Sea, eds M. Pastuszak, and J. Igras (Gdynia-Puławy: National Marine Fisheries Research Institute-Institute of Soil Science and Plant Cultivation-State Research Institute-Fertilizer Research Institute), 15-44.

Pastuszak, M. (2012b). "Excessive silicon retention - implications for marine environment," in Temporal and Spatial Differences in Emission of Nitrogen and Phosphorus From Polish Territory to the Baltic Sea, eds M. Pastuszak, and J. Igras (Gdynia-Puławy: National Marine Fisheries Research Institute-Institute of Soil Science and Plant Cultivation - State Research Institute-Fertilizer Research Institute), 383-417

Pastuszak, M., Bryhn, A., Håkanson, L., Stålnacke, P., Zalewski, M., and Wodzinowski, T. (2018). Reduction of nutrient emission from Polish territory to the Baltic Sea (1988-2017) confronted with real environmental needs and international requirements. Oceanol. Hydrobiol. Stud. 17, 140-160. doi: 10.1515/ohs-2018-0015

Pastuszak, M., and Igras, J. (2012). Temporal and Spatial Differences in Emission of Nitrogen and Phosphorus From Polish Territory to the Baltic Sea. GdyniaPuławy: National Marine Fisheries Research Institute-Institute of Soil Science and Plant Cultivation - State Research Institute-Fertilizer Research Institute.

Pastuszak, M., Kowalkowski, T., and Igras, J. (2012a). "Nitrogen and phosphorus emission into the Vistula and Oder basins- modeling studies (MONERIS)," in Temporal and Spatial Differences in Emission of Nitrogen and Phosphorus From Polish Territory to the Baltic Sea, eds M. Pastuszak, and J. Igras (Gdynia-Puławy: National Marine Fisheries Research Institute-Institute of Soil Science and Plant Cultivation-State Research Institute-Fertilizer Research Institute), 265-308.

Pastuszak, M., Nagel, K., Grelowski, A., Mohrholz, V., and Zalewski, M. (2003). Nutrient dynamics in the Pomeranian Bay (southern Baltic): impact of the Oder River outflow. Estuaries 26, 1238-1254. doi: 10.1007/BF02803627

Pastuszak, M., Stålnacke, P., Pawlikowski, K., and Witek, Z. (2012b). Response of Polish rivers (Vistula, Oder) to reduced pressure from point sources and agriculture during the transition period (1988-2008). J. Mar. Syst. 94, 157-173.
Pastuszak, M., and Witek, Z. (2012a). Discharges of water and nutrients by the Vistula and Oder Rivers draining Polish territory. in Temporal and Spatial Differences in Emission of Nitrogen and Phosphorus From Polish Territory to the Baltic Sea, eds M. Pastuszak and J. Igras (Gdynia-Puławy: National Marine Fisheries Research Institute-Institute of Soil Science and Plant Cultivation-State Research Institute-Fertilizer Research Institute), 311-354.

Pastuszak, M., and Witek, Z. (2012b). "Role of the Oder and Vistula estuaries in retention of nitrogen and phosphorus loads directed to the Baltic Sea in riverine outflow," in Temporal and Spatial Differences in Emission of Nitrogen and Phosphorus From Polish Territory to the Baltic Sea, eds M. Pastuszak, and J. Igras (Gdynia-Puławy: National Marine Fisheries Research Institute-Institute of Soil Science and Plant Cultivation-State Research Institute-Fertilizer Research Institute), 357-379.

Pastuszak, M., Witek, Z., Nagel, K., Wielgat, M., and Grelowski, A. (2005). Role of the Oder estuary (southern Baltic) in transformation of the riverine nutrient loads. J. Mar. Syst. 57, 30-54. doi: 10.1016/j.jmarsys.2005.04.005

Pérez-Ruzafa, A., Hegazi, M., Pérez-Ruzafa, I., and Marcos, C. (2008). Differences in spatial and seasonal patterns of macrophyte assemblages between a coastal lagoon and the open sea. Mar. Environ. Res. 65, 291-314. doi: 10.1016/j.marenvres.2007.11.008

Pérez-Ruzafa, Á., Marcos, C., and Pérez-Ruzafa, I. M. (2018). "When maintaining ecological integrity and complexity is the best restoring tool: the case of the Mar Menor lagoon," in Management and Restoration of Mediterranean Coastal Lagoons in Europe (Recer. i territorio), eds X. Quintana, G. S. D. Boix, and J. Sala (les Illes Medes i el Baix Ter Museu de la Mediterrania: Catedra d'Ecosistemes Litorals Mediterranis Parc Natural del Montgri), 67-96.

Petersen, J. K., Hansen, J. W., Laursen, M. B., Clausen, P., Carstensen, J., and Conley, D. J. (2008). Regime shift in a coastal marine ecosystem. Ecol. Applic. 18, 497-510. doi: 10.1890/07-0752.1

Petkuviene, J., Zilius, M., Lubiene, I., Ruginis, T., Giordani, G., RazinkovasBaziukas, A., et al. (2016). Phosphorus cycling in a freshwater estuary impacted by cyanobacterial blooms. Estuar. Coasts 39, 1386-1402. doi: 10.1007/s12237-016-0078-0

Povilanskas, R., Razinkovas-Baziukas, A., and Jurkus, E. (2014). Integrated environmental management of transboundary transitional waters: Curonian Lagoon case study. Ocean Coast. Manag. 101, 14-23. doi: 10.1016/j.ocecoaman.2014.04.030

Radtke, H., Lipka, M., Bunke, D., Morys, C., Cahill, B., Böttcher, M. E., et al. (2018). Ecological ReGional Ocean Model with vertically resolved sediments (ERGOM SED 1.0): coupling benthic and pelagic biogeochemistry of the south-western Baltic Sea. Geosci. Model Develop. Discuss. 2018, 1-42. doi: 10.5194/gmd-2018-109

Radziejewska, T., and Schernewski, G. (2008). "The Szczecin (Oder-) Lagoon," in Ecology of Baltic Coastal Waters, ed U. Schiewer (Berlin; Heidelberg: Springer), $115-129$.

Riemann, B., Carstensen, J., Dahl, K., Fossing, H., Hansen, J. W., Jakobsen, H. H., et al. (2016). Recovery of Danish Coastal ecosystems after reductions in nutrient loading: a holistic ecosystem approach. Estuar. Coasts 39, 82-97. doi: 10.1007/s12237-015-9980-0

Ruoho-Airola, T., Eilola, K., Savchuk, O. P., Parviainen, M., and Tarvainen, V. (2012). Atmospheric nutrient input to the Baltic sea from 1850 to 2006: a reconstruction from modeling results and historical data. Ambio 41, 549-557. doi: 10.1007/s13280-012-0319-9

Sagert, S., Selig, U., and Schubert, H. (2008). Phytoplankton indicators for ecological classification of coastal waters along the German Baltic coast. Rost. Meeresbiolog. Beitr. 20, 45-69.

Savchuk, O. P., Gustafsson, B. G., and Müller-Karulis, B. (2012). BALTSEM-A Marine Model for The Decision Support Within the Baltic Sea Region. Baltic Nest Institute Technical Report 7, 55.

Scheffer, M. (2009). "Alternative stable states and regime shifts in ecosystems," in The Princeton Guide to Ecology, ed S. A. Levin (Princeton, NJ: Princeton University ), 395-406.

Schenk, F., and Zorita, E. (2012). Reconstruction of high resolution atmospheric fields for Northern Europe using analog-upscaling. Clim. Past Discuss. 8, 819-868. doi: 10.5194/cpd-8-819-2012

Schernewski, G., Behrendt, H., and Neumann, T. (2008). An integrated river basincoast-sea modelling scenario for nitrogen management in coastal waters. $J$. Coast. Conserv. 12, 53-66. doi: 10.1007/s11852-008-0035-6 
Schernewski, G., Fischer, E., Huttula, T., Jost, G., and Ras, M. (2012a). Simulation tools to support bathing water quality management: Escherichia coli bacteria in a Baltic lagoon. J. Coast. Conserv. 16, 473-488. doi: 10.1007/s11852-012-0202-7

Schernewski, G., Friedland, R., Buer, A.-L., Dahlke, S., Drews, B., Höft, S., et al. (2018). Ecological-social-economic assessment of zebra-mussel cultivation scenarios for the Oder (Szczecin) Lagoon. J. Coast. Conserv.

Schernewski, G., Friedland, R., Carstens, M., Hirt, U., Leujak, W., Nausch, G., et al. (2015). Implementation of European marine policy: new water quality targets for German Baltic waters. Mar. Policy 51, 305-321. doi: 10.1016/j.marpol.2014.09.002

Schernewski, G., Inacio, M., and Nazemtseva, Y. (2018). Expert based ecosystem service assessment in coastal and Marine planning and management: a baltic lagoon case study. Front. Environ. Sci. 6:19. doi: 10.3389/fenvs.2018. 00019

Schernewski, G., Neumann, T., and Behrendt, H. (2011). "Sources, dynamics and management of phosphorus in a Southern Baltic estuary," in The Baltic Sea Basin, eds J. Harff, S. Björck, and P. Hoth (Berlin;Heidelberg: Springer), 373-388.

Schernewski, G., Stybel, N., and Neumann, T. (2012b). Zebra mussel farming in the Szczecin (Oder) Lagoon: water-quality objectives and cost-effectiveness. Ecol. Soc. 17:4. doi: 10.5751/ES-04644-170204

Schippmann, B., Schernewski, G., Gräwe, U. (2013b). Escherichia coli pollution in a Baltic Sea lagoon: a model-based source and spatial risk assessment. Int. J. Hyg. Environ. Health 216, 408-420. doi: 10.1016/j.ijheh.2012.12.012

Schippmann, B., Schernewski, G., Gräwe, U., Burchard, H., and Walczykiewicz, T. (2013a). A model tool for bathing water quality management: a case study on Salmonella occurrence at the southern Baltic coast. Ocean Coast. Manag. 82, 71-84. doi: 10.1016/j.ocecoaman.2013.05.006

Schröder, T., Stank, J., Schernewski, G., and Krost, P. (2014). The impact of a mussel farm on water transparency in the Kiel Fjord. Ocean Coast. Manag. 101 (Pt A), 42-52. doi: 10.1016/j.ocecoaman.2014.04.034

Schubert, H., Wasmund, N., and Sellner, K. G. (2010). "Long-term investigations in Brackish ecosystems," in Long-Term Ecological Research: Between Theory and Application, eds F. Müller, C. Baessler, H. Schubert, and S. Klotz (Dordrecht: Springer), 163-178.

Selig, U., Eggert, A., Schories, D., Schubert, M., Blümel, C., and Schubert, H. (2007). Ecological classification of macroalgae and angiosperm communities of inner coastal waters in the southern Baltic Sea. Ecol. Indic. 7, 665-678. doi: 10.1016/j.ecolind.2006.07.006

Sinkevičienè, Z., Bučas, M., Ilginè, R., Vaičiūtè, D., Kataržytė, M., and Petkuvienè, J. (2017). Charophytes in the estuarine Curonian Lagoon: have the changes in diversity, abundance and distribution occurred since the late 1940s? Oceanol. Hydrobiol. Stud. 46, 186-198. doi: 10.1515/ohs-2017-0019

Søndergaard, M., Windolf, J., and Jeppesen, E. (1996). Phosphorus fractions and profiles in the sediment of shallow Danish lakes as related to phosphorus load, sediment composition and lake chemistry. Water Res. 30, 992-1002.

Stålnacke, P., and Grimvall, A. (2001). Semiparametric approaches to flow normalization and source apportionment of substance transport in rivers. Environmetrics 12, 233-250. doi: 10.1002/env.459

Stybel, N., Fenske, C., and Schernewski, G. (2009). "Mussel cultivation to improve water quality in the Szczecin Lagoon," in Proceedings of the 10th International Coastal Symposium ICS 2009, Vol. 2 (Lisbon: Journal of Coastal Research), 1459-1463.
Tomczak, M. T., Szymanek, L., Pastuszak, M., Grygiel, W., Zalewski, M., Gromisz, S., et al. (2016). Evaluation of Trends and Changes in the Gulf of Gdańsk ecosystem-an integrated approach. Estuar. Coasts 39, 593-604. doi: 10.1007/s12237-015-0026-4

Umgiesser, G., Ferrarin, C., Cucco, A., De Pascalis, F., Bellafiore, D., Ghezzo, M., et al. (2014). Comparative hydrodynamics of 10 Mediterranean lagoons by means of numerical modeling. J. Geophys. Res. Oceans 119, 2212-2226. doi: 10.1002/2013JC009512

Umgiesser, G., Zemlys, P., Erturk, A., Razinkova-Baziukas, A., Mežine, J., and Ferrarin, C. (2016). Seasonal renewal time variability in the Curonian Lagoon caused by atmospheric and hydrographical forcing. Ocean Sci. 12, 391-402. doi: 10.5194/os-12-391-2016

Venohr, M., Hirt, U., Hofmann, J., Opitz, D., Gericke, A., Wetzig, A., et al. (2011) Modelling of nutrient emissions in river systems - MONERIS - methods and background. Int. Rev. Hydrobiol. 96, 435-483. doi: 10.1002/iroh.201111331

WFD (2000/60/EC). Commission of the European Communities. Directive 2000/60/EC of the European Parliament and of the council of 23 October 2000 Establishing a Framework for Community Action in the Field of Water Policy. Official Journal of the European Communities L 327.

Wielgat, M. (2002). "Compilation of nutrient Loads for the Szczecin Lagoon (Southern Baltic)," in Baltic Coastal Ecosystems: Structure, Function and Coastal Zone Management, eds G. Schernewski and U. Schiewer (Berlin; Heidelberg: Springer), 75-91.

Wielgat, M., and Witek, Z. (2004). “A dynamic box model of the Szczecin Lagoon nutrient cycling and its first application to the calculation of the nutrient budget," in The Oder Estuary, Against the Background of the Water Framework Directive, eds G. Schernewski and T. Dolch (Warnemünde: Warnemünde: Marine Science Reports), 99-125.

Wolnomiejski, N., and Witek, Z. (2013). The Szczecin Lagoon Ecosystem: The Biotic Community of the Great Lagoon and its Food Web Model. London: Walter de Gruyter.

Wulff, F., Sokolov, A., and Savchuk, O. (2013). Nest-a decision support system for management of the Baltic Sea. A User manual. Stockholm: Baltic Nest Institue.

Zettler, M. L., Friedland, R., Gogina, M., and Darr, A. (2017). Variation in benthic long-term data of transitional waters: is interpretation more than speculation? PLOS ONE 12:e0175746. doi: 10.1371/journal.pone. 0175746

Zilius, M., Bartoli. M., Bresciani. M., Katarzyte. M., Ruginis. T., Petkuviene, J., et al. (2014). Feedback mechanisms between cyanobacterial blooms, transient hypoxia, and benthic phosphorus regeneration in shallow coastal environments. Estuar. Coasts 37, 680-694. doi: 10.1007/s12237-0139717-x

Conflict of Interest Statement: The authors declare that the research was conducted in the absence of any commercial or financial relationships that could be construed as a potential conflict of interest.

Copyright (C) 2019 Friedland, Schernewski, Gräwe, Greipsland, Palazzo and Pastuszak. This is an open-access article distributed under the terms of the Creative Commons Attribution License (CC BY). The use, distribution or reproduction in other forums is permitted, provided the original author(s) and the copyright owner(s) are credited and that the original publication in this journal is cited, in accordance with accepted academic practice. No use, distribution or reproduction is permitted which does not comply with these terms. 